\title{
Effect of heat-treated canola meal and glycerol inclusion on performance and gastrointestinal development of Holstein calves
}

\author{
K. Burakowska, ${ }^{1}$ P. Górka, ${ }^{2} \odot$ C. Kent-Dennis, ${ }^{1}$ Z. M. Kowalski, ${ }^{2} \odot$ B. Laarveld, ${ }^{1}$ and G. B. Penner ${ }^{1 *}$ \\ ${ }^{1}$ Department of Animal and Poultry Science, University of Saskatchewan, 51 Campus Dr., Saskatoon, Saskatchewan S7N 5A8, Canada \\ ${ }^{2}$ Department of Animal Nutrition and Dietetics, University of Agriculture in Kraków, al. Mickiewicza 24/28, 30-059 Kraków, Poland
}

\begin{abstract}
The objectives of this study were to assess the effect of using heat-treated canola meal (CM) and glycerol inclusion in starter mixtures on starter intake, growth, and gastrointestinal tract development in Holstein bull calves. In the first study, a protocol for the heat treatment of CM was evaluated by comparing commercial $\mathrm{CM}$ that was exposed to $0,100,110$, or $120^{\circ} \mathrm{C}$ of heat treatment for $10 \mathrm{~min}$. Following heat treatment, in situ crude protein $(\mathrm{CP})$ ruminal degradability and estimated intestinal $\mathrm{CP}$ digestibility were assessed. It was observed that the degradable fractions of dry matter and $\mathrm{CP}$ in $\mathrm{CM}$ decreased linearly with increasing temperature of heat treatment. The estimated intestinal $\mathrm{CP}$ digestibility was greatest when $\mathrm{CM}$ was heated to $110^{\circ} \mathrm{C}$. In the second study, 28 bull calves were used in a randomized complete block design. Calves were fed pelleted starters containing $\mathrm{CM}$ or $\mathrm{CM}$ that was heat-treated to $110^{\circ} \mathrm{C}$ for $10 \mathrm{~min}$. Diets also contained 0 or $5 \%$ glycerol on a dry matter basis. The study lasted $51 \mathrm{~d}$, ending on the first day of weaning. Starter intake, average daily gain (ADG), ruminal short-chain fatty acid concentrations, morphology of the rumen and small intestine, gene expression (MCT1, GPR 41, GPR 43, UTB, AQP3, PEPT1, PEPT2, ATB0+, and $E A A C 1)$ in the ruminal, jejunal, and ileal epithelium, and brush border enzyme activities in the duodenum, jejunum, and ileum were investigated. Few interactions between heat-treated CM and glycerol inclusion were observed. Feeding heat-treated CM did not affect starter intake. However, feeding heat-treated CM to calves tended to reduce ADG and decreased the weight of ruminal and jejunal tissue. Heat treatment did not affect gene expression or brush border enzyme activi-
\end{abstract}

Received December 28, 2019 .

Accepted April 21, 2020.

*Corresponding author: greg.penner@usask.ca ties in the small intestine. Glycerol inclusion tended to increase cumulative starter intake and increased cumulative body weight gain. Use of glycerol reduced ruminal $\mathrm{pH}$ and increased the concentration of ruminal short-chain fatty acids. Additionally, glycerol inclusion increased abomasal, duodenal, jejunal, and cecal digesta weights and tended to increase the weight of the jejunal tissue. Glycerol supplementation tended to downregulate the expression of MCT1 in the ruminal epithelium, and upregulated the expression of MCT1 in the epithelium of proximal jejunum. In conclusion, heat treatment of CM may negatively affect calf growth and gastrointestinal tract development. Glycerol inclusion may increase starter intake, ADG, ruminal fermentation, and intestinal development in calves when CM is used as a main source of protein in pelleted starter mixture.

Key words: brush border enzymes, gene expression, intestine, rumen

\section{INTRODUCTION}

The weaning transition represents a critical phase for calves (Weary et al., 2008), with marked nutritional changes occurring as the provision of milk is reduced and calves start to rely on solid feed intake. The shift from milk to solid feed both stimulates and relies on gastrointestinal tract (GIT) development (Roth et al., 2009; Khan et al., 2016). Though considerable focus has been placed on stimulating ruminal digestion around weaning as a strategy to promote ruminal development, Górka et al. (2011) reported that development of the small intestine may also influence ruminal development. As such, dietary strategies that provide nutrients to promote ruminal fermentation while ensuring substrate availability in the small intestine may provide benefit for calves at weaning.

Canola meal $(\mathbf{C M})$ is a common protein source used in diets for lactating cows and has been reported to increase milk yield when used as a replacement for soybean meal or wheat dried distiller grains (Huhtanen et al., 2011; Martineau et al., 2013). However, CM is 
not commonly used in diets for calves around weaning due to concerns over palatability (Miller-Cushon et al., 2014a,b) and digestibility (Fiems et al., 1985; Khorasani et al., 1990). In contrast, some studies have suggested that CM inclusion has limited effects on starter intake and growth, at least when inclusion is limited to a portion of the soybean meal (Claypool et al., 1985; Hadam et al., 2016). However, mildly heattreated CM might be beneficial because it may increase the RUP fraction (McKinnon et al., 1991) and deliver a greater supply of AA to calves, and thus potentially hasten small intestine development, starter intake, and consequently, whole GIT development in calves before weaning. Nevertheless, the effect of heat-treated sources of protein, likely to increase rumen bypass protein content in starter feed, for calves at weaning has not been extensively evaluated.

Glycerol is a byproduct of bio-diesel production (Gerpen, 2005) that is rapidly fermented in the rumen (Rémond et al., 1993) and shifts fermentation to increase the proportion of butyrate and propionate in ruminal fluid (Rémond et al., 1993; Paiva et al., 2016). Butyrate is known to stimulate development of the ruminal epithelium (Sander et al., 1959; Mentschel et al., 2001), and thus glycerol may be a valuable feed ingredient in diets for calves during the weaning transition. Additionally, due to its sweet taste (Quispe et al., 2013), glycerol may improve palatability of feed, which may be an important contributing factor when CM is used as a source of protein in calf starters.

We hypothesized that the use of heat-treated CM in a starter mixture will promote the development of the small intestine, likely through greater supply of AA to the small intestine, which will have a positive effect on starter intake and intestinal and ruminal development. Finally, we hypothesized that glycerol inclusion in a starter mixture containing CM would increase the proportion of butyrate in ruminal fluid, and thus further stimulate ruminal development and starter intake. The objectives were to evaluate the optimal heat-treatment temperature of $\mathrm{CM}$ in regard to ruminal and estimated intestinal digestibility of nutrients, and to determine the effect of CM heat treatment, glycerol supplementation, and their interaction on starter intake, calf growth, and the development of the GIT of dairy calves at weaning.

\section{MATERIALS AND METHODS}

Experimental procedures were pre-approved by the University of Saskatchewan Animal Research Ethics Board (protocol no. 20100021) in accordance with the guidelines of the Canadian Council on Animal Care (Ottawa, ON, Canada).

\section{Study 1: Optimal Heat-Treatment Temperature of CM}

Heat Treatment of CM. Four subsamples of commercial solvent-extracted CM (100 kg each) from a single source were used to evaluate the effect of heattreated CM on in situ ruminal and estimated intestinal CP digestibility. For each treatment, a $25-\mathrm{kg}$ portion from each subsample was subjected to 1 of 4 treatments: (1) no additional heat (CON), or (2) additional heat treatment to achieve a temperature of $100^{\circ} \mathrm{C}(\mathbf{H}-$ 100), (3) $110^{\circ} \mathrm{C}(\mathbf{H}-\mathbf{1 1 0})$, or (4) $120^{\circ} \mathrm{C}(\mathbf{H}-\mathbf{1 2 0})$. All treatment temperatures were held at the designated temperature for 10 min (McKinnon et al., 1991, 1995). Heat treatment was conducted in a tumble dryer (POS Bioscience, Saskatoon, SK, Canada) and the temperature was steadily increased from ambient temperature to the treatment temperature. Following $10 \mathrm{~min}$ of heat exposure at the specific temperature, the $\mathrm{CM}$ was cooled to $50^{\circ} \mathrm{C}$. A total of (mean \pm SEM) $26 \pm 2.1 \mathrm{~min}$ for $\mathrm{H}-100,43 \pm 4.4 \mathrm{~min}$ for $\mathrm{H}-110$, and $67 \pm 6.7 \mathrm{~min}$ for $\mathrm{H}-120$ were required to achieve target temperatures. The durations required for cooling were $21 \pm 2.3 \mathrm{~min}$ for $\mathrm{H}-100,24 \pm 4.1 \mathrm{~min}$ for $\mathrm{H}-110$, and $30 \pm 0.3 \mathrm{~min}$ for H-120. All temperature changes occurred linearly.

In Situ Ruminal Degradability. Four ruminally cannulated (internal diameter of $10 \mathrm{~cm}$, Bar Diamond Inc., Parma, ID) Hereford-cross heifers $(616 \pm 26.0 \mathrm{~kg}$, initial $\mathrm{BW} \pm \mathrm{SD}$ ) were used for in situ incubations. Heifers were housed in individual pens $(3 \times 3 \mathrm{~m})$ at the Livestock Research Building (University of Saskatchewan, Saskatoon, SK, Canada) and were fed a TMR twice a day at 0900 and $1700 \mathrm{~h}$. The diet consisted of barley silage (25\% DM), rolled barley grain ( $47 \% \mathrm{DM})$, grass hay $(20 \% \mathrm{DM})$, and a mineral and vitamin pellet $(8 \% \mathrm{DM})$ with the amount of TMR provided at $2.5 \%$ of BW. Feed refusals were weighed and collected daily at $0830 \mathrm{~h}$. Barley grain and the mineral and vitamin pellet samples were collected once per week and forage samples were collected twice per week. Feed and refusal samples were analyzed for DM content by drying at $55^{\circ} \mathrm{C}$ in a forced-air oven until achieving a constant weight. The DM content of the ingredients was used to adjust their proportions in the diet on an as-fed basis, as necessary. Feed samples were ground to pass through a 1-mm sieve (Christy and Norris, Christy Turner Ltd., Chelmsford, UK) and were pooled by sampling date and analyzed for chemical composition as described below.

Empty polyester bags $(53 \pm 10 \mu \mathrm{m}$ pore size; \#BG510, Bar Diamond Inc.) were dried to $55^{\circ} \mathrm{C}$ for $1 \mathrm{~h}$, placed in a desiccator for $15 \mathrm{~min}$, and weighed. Approximately $7 \mathrm{~g}$ of $\mathrm{CM}$ was weighed into each bag and then sealed. The sequential-in all-out procedure, 
as recommended by the NRC (2001), was used for in situ incubations. Incubation times for the nylon bags were $0,2,4,8,12,16,24$, and $48 \mathrm{~h}$. Incubations were completed in 2 separate, consecutive, randomized runs with treatments and times balanced among heifers. $\mathrm{Ny}-$ lon bag insertion into the rumen was initiated at 0900 $\mathrm{h}$ on $\mathrm{d} 1$ and all bags were removed at $0900 \mathrm{~h}$ on $\mathrm{d} 3$. Bags for the $0 \mathrm{~h}$ of incubation were soaked in warm (37 to $39^{\circ} \mathrm{C}$ ) distilled water for $30 \mathrm{~min}$. As the in situ incubation approach used a sequential-in all-out method, the number of nylon bags inserted into a single heifer did not exceed 44 bags. In addition, 4 bags for each treatment replicate were incubated for $12 \mathrm{~h}$ to allow for a 3-step in vitro procedure to measure estimated intestinal digestibility (Calsamiglia and Stern, 1995).

Upon removal from the rumen, bags were immediately placed in cold water $\left(4^{\circ} \mathrm{C}\right)$ and washed 5 times. For each wash, 60 bags were placed in $15 \mathrm{~L}$ of cold water and manually agitated for $1 \mathrm{~min}$. After washing, bags were placed on a flat pan and frozen at $-20^{\circ} \mathrm{C}$ for $24 \mathrm{~h}$. Following this step, bags were removed from the freezer, placed in cold water, and rinsed 1 additional time to reduce microbial contamination (Kamel et al., 1995). The bags were then dried at $55^{\circ} \mathrm{C}$ until achieving a constant weight, placed in desiccators for $15 \mathrm{~min}$, and weighed. The residual feed from each time point within a treatment replicate were pooled for chemical analysis.

Estimated Intestinal Digestibility. The 3-step estimated intestinal digestibility procedure was conducted as described by Calsamiglia and Stern (1995). The residuals remaining after $12 \mathrm{~h}$ of ruminal incubation were pooled for each treatment and subjected to digestion in pepsin (1 g/L; No. P-7012, Sigma, St. Louis, MO) and $\mathrm{HCl}(0.1 \mathrm{~N})$ for $1 \mathrm{~h}$ at $38^{\circ} \mathrm{C}$ in a shaking water bath. Samples were then neutralized using 1 $N$ sodium hydroxide and subsequently incubated in the presence of pancreatin (3 g/L; No. P-7545, Sigma; in 0.5 $M \mathrm{KH}_{2} \mathrm{PO}_{4}$ buffer) for $24 \mathrm{~h}$. During incubation, samples were placed in a shaking water bath $\left(38^{\circ} \mathrm{C}\right)$. At the end of incubation, enzymatic activity was stopped by addition of trichloroacetic acid $(100 \% \mathrm{wt} / \mathrm{vol}, \mathrm{T} 6399$, Sigma). Samples were then stored at $4^{\circ} \mathrm{C}$ until further analysis of CP content.

Chemical Analysis of Feed and In Situ Samples. Analytical DM content was determined by drying samples at $135^{\circ} \mathrm{C}$ for $2 \mathrm{~h}$. Crude protein concentration was measured using the Kjeldahl method (984.13, AOAC International, 1994). Ash was determined according to method 942.05 (AOAC International, 1994) and was used to calculate OM concentration. The NDF and $\mathrm{ADF}$ concentrations were analyzed independently using Ankom F57 filter bags in the Ankom 200 Fiber Analyzer (ANKOM Technology Corp., Fairport, NY) according to the method of van Soest et al. (1991); NDF samples were treated with $\alpha$-amylase and sodium sulfite. Ether extract analysis was carried out in Goldfisch Fat Extraction Apparatus (Model 35001, Goldfisch, ExpoTechUSA, Houston, TX) according to method 920.39 (AOAC International, 1994). Amino acid concentrations of the CM samples were analyzed by Evonic Nutrition and Care GmbH (Essen, Germany).

\section{Study 2: Effect of Heat-Treated CM and Glycerol on Calves}

Animals, Housing, and Feeding Regimen. Twenty-eight newborn bull calves were sourced from a single commercial herd near Saskatoon (SK, Canada) for this study. All calves were separated from their dam immediately after birth and provided a commercial colostrum replacer (Headstart bovine dried colostrum; The Saskatoon Colostrum Co. Ltd., Saskatoon, SK, Canada) to target total supply of $180 \mathrm{~g}$ of $\mathrm{IgG}$ within first $12 \mathrm{~h}$ of life. Two bags of colostrum replacer (120 $\mathrm{g}$ of $\operatorname{IgG}$ ) were fed within $6 \mathrm{~h}$ of birth, and a third bag (60 $\mathrm{g}$ of $\operatorname{IgG}$ ) was fed within $12 \mathrm{~h}$ of birth. Colostrum replacer was fed from a bottle with a nipple. Following colostrum, all calves received a commercial milk replacer (Grober Nutrition, Cambridge, ON, Canada) containing dried skim milk powder (Grober Energy Supplement 983681), dried whey powder, vegetable oil, Grober rearing premix (950261), autolyzed yeast, soy lecithin, calcium chloride, DL-methionine, calcium carbonate L-lysine, flavor (983030; Grober Nutrition), viable microbial product (982931; Grober Nutrition), polyethylene glycol, mono and di-oleates, and seleniumenriched yeast (982026; Grober Nutrition) with a mixing rate of $150 \mathrm{~g}$ (DM basis) of milk replacer powder in $1 \mathrm{~L}$ of water. (Table 1). Until $7 \mathrm{~d}$ of age, all calves were fed $4 \mathrm{~L} / \mathrm{d}$ of milk replacer in 2 equal feedings. Within 1 wk of birth $(3.6 \pm 2.1 \mathrm{~d}$ of age), calves were transported to the Livestock Research Building (University of Saskatchewan, Saskatoon, SK, Canada). Upon arrival, calves were placed in individual pens $(1.2 \times 2.4$ $\mathrm{m})$ with wood shavings as bedding. Bedding was kept at a minimum and replaced as needed.

At $8 \mathrm{~d}$ of age calves were weighed (mean $43.2 \pm$ $3.9 \mathrm{~kg}$ ) and BW was recorded weekly thereafter. The amount of milk replacer provided was adjusted to deliver $10 \% \mathrm{BW}$ on $\mathrm{d} 8$ and $9,11.5 \% \mathrm{BW}$ on $\mathrm{d} 10$ and $11,13 \%$ BW on d 12 and 13, and 15\% BW from d 14 until d 28 of age with the milk replacer fed in 3 equal feedings at 0800,1200 , and $1600 \mathrm{~h}$. Calves were exposed to a gradual weaning protocol by reducing the amount of milk replacer offered to $10 \%$ of BW starting on d 29 , $5 \%$ BW starting on d 36 (both fed in 2 equal feedings at 0800 and $1600 \mathrm{~h}$ ), and $2.5 \% \mathrm{BW}$ from $\mathrm{d} 43$ (fed in 1 feeding at $0800 \mathrm{~h}$ ) with no further milk replacer offered 
after d 50. The amount of milk replacer offered and refused were recorded at each feeding and summarized to reflect each feeding level and the cumulative amount fed over the course of the study. Representative samples of milk replacer were collected from each $25-\mathrm{kg}$ bag and used for DM analysis to monitor and ensure the mixing rate was static at $150 \mathrm{~g}$ of DM/L. Samples of milk replacer were also composited monthly and used for chemical analysis (described below).

Calves were blocked by birth date and within block randomly assigned to 1 of 4 treatments, using BW at 8 $\mathrm{d}$ of age as a secondary blocking factor. The treatments differed in composition of offered pelleted starter mixtures that contained: (1) CM without glycerol (NHNG), (2) CM with glycerol (NH-G), (3) heat-treated CM without glycerol (H-NG), or (4) heat-treated CM with glycerol $(\mathbf{H}-\mathbf{G})$ in a $2 \times 2$ factorial arrangement (Table 1). Starters were formulated to be isonitrogenous and isoenergetic. To balance the nitrogen content between glycerol supplemented and nonsupplemented diets, urea was included in the glycerol starters. Based on results of study 1 (see Results section), the heattreated CM was heated in a tumble dryer (POS, Saskatoon) at $110^{\circ} \mathrm{C}$ for 10 min before mixing and pelleting. The crude glycerol made from soybean (minimum of $80 \%$ purity and maximum of $2.30 \%$ sodium) was sourced from Canadian Feed Research Centre (North Battleford, SK, Canada) and was included at $5 \%$ of the pellet DM. Glycerol was included in the starters in exchange for barley grain. Starter mixtures were pelleted at the Canadian Feed Research Centre. First, the starter mash was prepared for pelleting with UASMuyang pellet conditioner (model MUTZ350-J Triple layered twin; Muyang, Yangzhou, China) by addition of $2.5 \%$ moisture at atmospheric pressure. Next, the mash was pelleted using a $3.5-\mathrm{mm}$ die at $65^{\circ} \mathrm{C}$ for 20 to 25 $\mathrm{s}$ in the UAS-Muyang pellet mill (model MUZL350II). The compression ratio of the die was 14.0 as calculated by dividing the effective length of the die hole $(50 \mathrm{~mm})$ by the diameter of the die hole $(3.57 \mathrm{~mm})$. Pellets were then cooled to $5^{\circ} \mathrm{C}$ above ambient temperature in a UAS-Muyang counter-flow cooler (model SLNF14X14A). Pelleting added 2.5\% moisture, which was removed by the cooling process.

Starter was offered from d 8 of age at a rate of 400 $\mathrm{g} / \mathrm{d}$ and the amount was adjusted daily to ensure ad libitum intake by increasing the amount offered by $500 \mathrm{~g}$ when refusals dropped below $250 \mathrm{~g}$ initially, and when refusals were less than $500 \mathrm{~g}$ for the rest of the study. Refusals of the starter were removed and

Table 1. Ingredient and nutrient composition of pelleted starter mixtures containing canola meal either nonheated (NH) or heated to $110^{\circ} \mathrm{C}$ for 10 min $(\mathrm{H})$, without $(\mathrm{NG})$ or with $(\mathrm{G})$ inclusion of $5 \% \mathrm{DM}$ of glycerol, and nutrient composition of milk replacer

\begin{tabular}{|c|c|c|c|c|c|}
\hline \multirow[b]{2}{*}{ Item } & \multicolumn{4}{|c|}{ Treatment } & \multirow{2}{*}{$\begin{array}{c}\text { Milk } \\
\text { replacer }{ }^{1}\end{array}$} \\
\hline & NH-NG & $\mathrm{NH}-\mathrm{G}$ & $\mathrm{H}-\mathrm{NG}$ & $\mathrm{H}-\mathrm{G}$ & \\
\hline Nonheated canola meal & 34.00 & 34.00 & - & - & \\
\hline Heated canola meal & - & - & 34.00 & 34.00 & \\
\hline Barley grain & 32.00 & 26.82 & 32.00 & 26.82 & \\
\hline Corn grain & 29.00 & 29.00 & 29.00 & 29.00 & \\
\hline Urea & - & 0.18 & - & 0.18 & \\
\hline Glycerol & - & 5.00 & - & 5.00 & \\
\hline \multicolumn{6}{|l|}{ Chemical composition, ${ }^{3} \%$ of DM } \\
\hline DM, $\%$ & $91.5 \pm 0.6$ & $91.5 \pm 0.8$ & $92.6 \pm 0.2$ & $92.7 \pm 0.8$ & $93.2 \pm 0.9$ \\
\hline $\mathrm{CP}$ & $20.4 \pm 0.5$ & $20.6 \pm 0.5$ & $21.2 \pm 0.7$ & $21.2 \pm 0.4$ & $27.3 \pm 0.7$ \\
\hline $\mathrm{ADF}$ & $10.2 \pm 0.2$ & $10.1 \pm 0.4$ & $10.3 \pm 0.2$ & $10.7 \pm 0.3$ & $\mathrm{NA}^{4}$ \\
\hline NDF & $16.1 \pm 0.2$ & $17.1 \pm 0.8$ & $17.0 \pm 0.4$ & $17.0 \pm 0.2$ & $\mathrm{NA}$ \\
\hline $\mathrm{P}$ & $0.96 \pm 0.0$ & $0.94 \pm 0.0$ & $0.97 \pm 0.0$ & $1.01 \pm 0.0$ & $0.9 \pm 0.0$ \\
\hline
\end{tabular}

${ }^{1}$ Grober Nutrition (Cambridge, ON, Canada). The milk replacer contained dried skim milk powder (Grober energy supplement 983681), dried whey powder, vegetable oil, Grober rearing premix (950261), autolyzed yeast, soy lecithin, calcium chloride, DL-methionine, calcium carbonate L-lysine, flavor (983030), viable microbial product (982931), polyethylene glycol, mono- and di-oleates, and selenium yeast (982026).

${ }^{2}$ Composition: Ca 1.2\%; P 0.6\%; Mg 0.4\%; K 1.2\%; S 0.3\%; Na 0.4\%; Cl 0.7\%; Se 0.5\%; Fe 230 mg/kg; Mn 120 mg/kg; Zn 220 mg/kg; Cu 50 $\mathrm{mg} / \mathrm{kg}$; vitamin A 10,000 IU; vitamin D 1,600 IU; vitamin E $50 \mathrm{mg}$.

${ }^{3}$ Mean \pm SD.

${ }^{4} \mathrm{NA}=$ not analyzed. 
recorded daily before the morning milk replacer feeding, and fresh starter offered after provision of milk replacer. Furthermore, refusals from each calf were collected and pooled on a weekly basis and analyzed for DM as previously described. In addition, samples of starters were collected weekly for DM determination and chemical analysis. Samples were then composited to yield a monthly sample for each treatment and were then ground to pass through a 1-mm sieve (ZM 200 Retsch, Haan, Germany). Data on starter intake were summarized to indicate starter intake from d 8 to 28 , 29 to 35,36 to 42 , and 43 to 49 to represent periods of time where milk replacer was provided at $15 \%$ of BW, $10 \%$ of BW, $5 \%$ of BW, and $2.5 \%$ of BW, respectively. In addition, cumulative starter intake over the duration of the study was calculated.

Samples of the starter pellets and milk replacer were sent to Cumberland Valley Analytical Services (Hagerstown, MD) for analysis of DM, CP, ether extract, OM, ADF, NDF, starch, ethanol soluble carbohydrates, Ca, and P. Dry matter was analyzed using method 930.15 by drying the sample at $135^{\circ} \mathrm{C}$ (AOAC International, 2000). Crude protein was analyzed using method 990.03 (AOAC International, 2000) using Leco FP-528 Nitrogen Combustion Analyzer (Leco, St. Joseph, MI). Acid detergent fiber was analyzed using method 973.18 (AOAC International, 2000) with modifications; we used Whatman 934-AH glass microfiber filters with $1.5-\mu \mathrm{m}$ particle retention. Neutral detergent fiber was analyzed as described by van Soest et al. (1991) using sodium sulfate and $\alpha$-amylase with the same microfiber filters as used for ADF. Starch was analyzed according to Hall (2009). Ethanol soluble carbohydrates were analyzed according to DuBois et al. (1956). Ether extract was analyzed using method 2003.05 (AOAC International, 2006) using Tecator Soxtec System HT 1043 Extraction unit (Tecator, Foss, Eden Prairie, MN). To calculate OM, ash was analyzed with method 942.05 (AOAC International, 2000) using a 1.5-g sample with a 4 -h ashing duration. Mineral analysis was conducted using method 985.01 (AOAC International, 2000) and Perkin Elmer 5300 DV ICP (Perkin Elmer, Shelton, CT).

Blood Sample Collection and Analysis. Blood samples were collected on d $22(15 \%$ BW of milk replacer provision), d 43 (5\% BW of milk replacer provision) and on $\mathrm{d} 51$ ( $1 \mathrm{~d}$ after weaning) from the jugular vein at $1000 \mathrm{~h}$ ( $2 \mathrm{~h}$ postfeeding). Two samples $(10 \mathrm{~mL}$ each $)$ were collected at each time point with blood placed in a tube containing Na-heparin (plasma separation; 158 IU, Becton Dickinson, Franklin Lakes, NJ) and a tube without anticoagulant (serum separation; Becton Dickinson). Blood collected into the tube with Na-heparin was immediately placed on ice until centrifugation for 15 min at 2,600 $\times g$ at $4^{\circ} \mathrm{C}$ (Sorvall ST $16 \mathrm{R}$, Thermo
Scientific, Waltham, MA), whereas blood collected into the tube without an anticoagulant was allowed to clot for $1 \mathrm{~h}$ before centrifugation at the same conditions as for plasma separation. The supernatant from both samples was then transferred into separate vials and frozen at $-20^{\circ} \mathrm{C}$ until analysis of glucose, insulin, BHB, nonesterified fatty acids (NEFA), and urea.

Plasma glucose concentration was analyzed by enzymatic reaction of glucose with glucose oxidase/ peroxidase (No. P7119 Sigma) and dianisidine dihydrochloride (No. D3252 Sigma) in a 96-well plate and the absorbance was measured at $450 \mathrm{~nm}$ using a plate reader (Epoch 2, BioTek Instruments Inc., Winooski, VT). Plasma insulin concentration was analyzed using a bovine-specific ELISA kit (no. 10-120-01, Mercodia, Uppsala, Sweden). The BHB concentration in serum was measured based on the method described by Williamson et al. (1962). Plasma NEFA concentration was analyzed using a commercial kit (HR Series NEFAHR(2); Wako Diagnostics, Mountain View, CA) using 2 solvents (no. 995-34791 and 993-35191) and 2 color reagents (no. 999-34691 and 991-34891). Plasma urea concentration was analyzed using the method described by Fawcett and Scott (1960).

Postslaughter Data and Sample Collection. One day after weaning (d 51), all calves were killed via captive bolt stunning followed by exsanguination at $1400 \mathrm{~h}$, or at $1330 \mathrm{~h}$ and $1430 \mathrm{~h}$ if 2 calves were killed on the same day. The whole GIT was dissected to determine tissue and digesta weights and to obtain tissue and digesta samples. The weights, both with and without digesta, were recorded for the reticulo-rumen, omasum, abomasum, duodenum, jejunum, ileum, cecum, and colon. The reticulo-rumen was cut open along the dorsal sac and digesta was transferred into a clean container. Ruminal tissue samples were collected from the cranial ventral sac of the rumen. For intestinal tissues, length measurements were conducted for each region. Then, tissue samples were taken from the mid-point of the duodenum (the distal portion of the duodenum was determined at the ligament of Treitz), 3 regions of jejunum including the proximal (25\% of the total length starting at the ligament of Treitz), middle (50\% of the length), and distal regions ( $75 \%$ of the length) with the region adjacent to the ileocecal fold used to denote the end of the jejunum and start of the ileum. The mid-point of the ileum was also collected using the ileocecal fold and ileocecal junction to define the ileum. All tissue samples were gently washed in ice-cold sterile phosphate buffered saline (Sigma) to remove digesta before any further processing.

Ruminal Fermentation Characteristics. A representative sample of ruminal digesta was strained through 2 layers of cheesecloth and $\mathrm{pH}$ was measured 
using a portable $\mathrm{pH}$ meter (Accumet AP110, Fischer Scientific, Ottawa, ON, Canada). Ten milliliters of strained ruminal fluid was mixed with $2 \mathrm{~mL}$ of metaphosphoric acid (25\% wt/vol). The sample was stored at $-20^{\circ} \mathrm{C}$ until analysis of short-chain fatty acid (SCFA) concentration with gas chromatography (Agilent Technologies Inc., Santa Clara, CA) as described by Khorasani et al. (1996). A second sample of strained ruminal fluid $(10 \mathrm{~mL})$ was collected and mixed with 2 $\mathrm{mL}$ of $1 \%$ sulfuric acid and frozen at $-20^{\circ} \mathrm{C}$ until analysis of ammonia concentration based on the method described by Fawcett and Scott (1960).

Tissue Collection for Gene Expression. Representative tissues from the cranial sac of the rumen (CRA), proximal jejunum (PROX), and ileum (ILE) were used to obtain epithelia and to measure the mRNA expression of selected target genes (Table 2). The genes of interest were monocarboxylate transporter 1 (MCT1) analyzed in CRA, PROX, and ILE; G-protein-coupled receptors (GPR41, GPR 43) analyzed in CRA, PROX, and ILE; urea transporters (UTB and AQP3) analyzed in CRA; peptide transporters (PEPT1 and PEPT2) and amino acid transporters (EAAC1 and ATBO+) analyzed in PROX and ILE; as well as reference genes (GAPDH, RPLP0, and HPRT1) analyzed in CRA, PROX, and ILE. The ruminal epithelium was manually peeled from the underlying muscle layer and cut into small pieces, the samples of the intestinal tissues were cut open through the mesenteric line, and the mucosa was scraped off using a glass slide. All tissues were collected using sterile equipment, rinsed in sterile ice-cold phosphate buffered saline, and transferred to 2-mL test tubes with $1.8 \mathrm{~mL}$ of RNAlater solution (Applied Biosystems, Foster City, CA). Tubes were stored for $24 \mathrm{~h}$ at $4^{\circ} \mathrm{C}$ and then frozen at $-20^{\circ} \mathrm{C}$.

Quantitative Real-Time PCR. Samples of epithelia were thawed, removed from RNAlater, and ground with a mortar and pestle while purged with liquid nitrogen to keep the tissue frozen. Approximately $100 \mathrm{mg}$ of tissue was transferred into a 2-mL sterile microcentrifuge tube. We extracted RNA through the phenol-chloroform extraction process based on the Chomczynski and Sacchi (1987) and Trizol (Thermo Fisher Scientific) protocols, with an additional isopropanol precipitation step.

The nucleic acid concentration and the 260:280 nm absorbance ratio were measured using a Nanodrop 2000c spectrophotometer (Thermo Scientific). Samples were then evaluated for RNA integrity on a $1.2 \%$ agarose denaturing gel. The RNA was considered good quality if there was distinct separation of the $18 \mathrm{~S}$ and $28 \mathrm{~S}$ ribosomal RNA bands. Four samples were suspected to contain genomic DNA contamination. As such, they were DNase-treated using the TURBO DNA-free
Kit (Thermo Fisher Scientific) and re-evaluated on the agarose gel to ensure lack of contamination.

For each sample, $2 \mu \mathrm{g}$ of RNA was reverse transcribed to produce cDNA (High-Capacity cDNA Reverse Transcription Kit, Applied Biosystems). Primer (Table 2) efficiency was determined (Ramakers et al., 2003) using a composite sample of cDNA from all calves in the study. The melting curve of the primers was analyzed to ensure their specificity. The primer efficiency values ranged from 98 to $110 \%$, with an average of $103.6 \%$. Quantitative real-time PCR was carried out using the CFX96 Real-Time PCR system and SsoFast EvaGreen Supermix (Bio-Rad, Hercules, CA). We ran the reaction in duplicate with different gastrointestinal regions for the same gene analyzed on consecutive 96 -well plates (Bio-Rad).

The expression $\left(\mathbf{C}_{\mathbf{T}}\right.$, threshold cycle) of reference genes (GAPDH, RPLPO, HPRT1) in all analyzed regions of GIT were used to determine whether there were differences between the treatments. All 3 reference genes were deemed to have stable $\mathrm{C}_{\mathrm{T}}$ as treatment effects were not present $(P \geq 0.15$, data not shown). The expression of target genes was analyzed by calculating the difference between the $\mathrm{C}_{\mathrm{T}}$ for the gene of interest and the geometric mean of $\mathrm{C}_{\mathrm{T}}$ for the reference genes $\left(\Delta \mathbf{C}_{\mathrm{T}}\right)$. With gene expression calculated in this manner, greater $\Delta \mathrm{C}_{\mathrm{T}}$ values indicate lesser mRNA expression, and lesser $\Delta \mathrm{C}_{\mathrm{T}}$ values indicate greater expression.

Brush Border Enzyme Activity Assays. The epithelium from the duodenum, the proximal, middle, and distal jejunum, and the ileum were scraped using sterile glass slides on a clean surface on ice. Epithelia samples were placed into 2 -mL cryo-vials, snap frozen in liquid nitrogen, and then stored at $-80^{\circ} \mathrm{C}$ until analysis of lactase (EC 3.2.1.23), maltase (EC 3.2.1.20), dipeptidase IV (EC 3.4.14.5), aminopeptidase A (EC 3.4.11.7), and N (EC 3.4.11.2) enzyme activity (Maroux et al., 1973; Nagatsu et al., 1976; Dahlqvist, 1984). Briefly, small intestine mucosa samples were thawed on ice and $1 \mathrm{~g}$ of tissue was weighed and transferred into a $10-\mathrm{mL}$ vial. Five milliliters of reverse osmosis water was added per $1 \mathrm{~g}$ of tissue and samples were then homogenized for $30 \mathrm{~s}$, and following a $10 \mathrm{~s}$ break, for another $30 \mathrm{~s}$, while kept on ice at all times. The homogenate was centrifuged (SORVALL ST 16R, Thermo Scientific) at $1,000 \times g, 4^{\circ} \mathrm{C}$ for $5 \mathrm{~min}$ and the supernatant was transferred into multiple $1.5-\mathrm{mL}$ tubes and frozen at $-80^{\circ} \mathrm{C}$.

Protein content was determined for each supernatant of tissue homogenate using the bicinchoninic acid method described by Smith et al. (1985). Lactase and maltase were analyzed according to Dahlqvist (1984) with minor modifications. The released glucose was measured according to the same procedure as plasma glucose described above. The L-glutamyl- $p$-nitroanilide 
Burakowska et al.: HEAT-TREATED CANOLA MEAL AND GLYCEROL INCLUSION

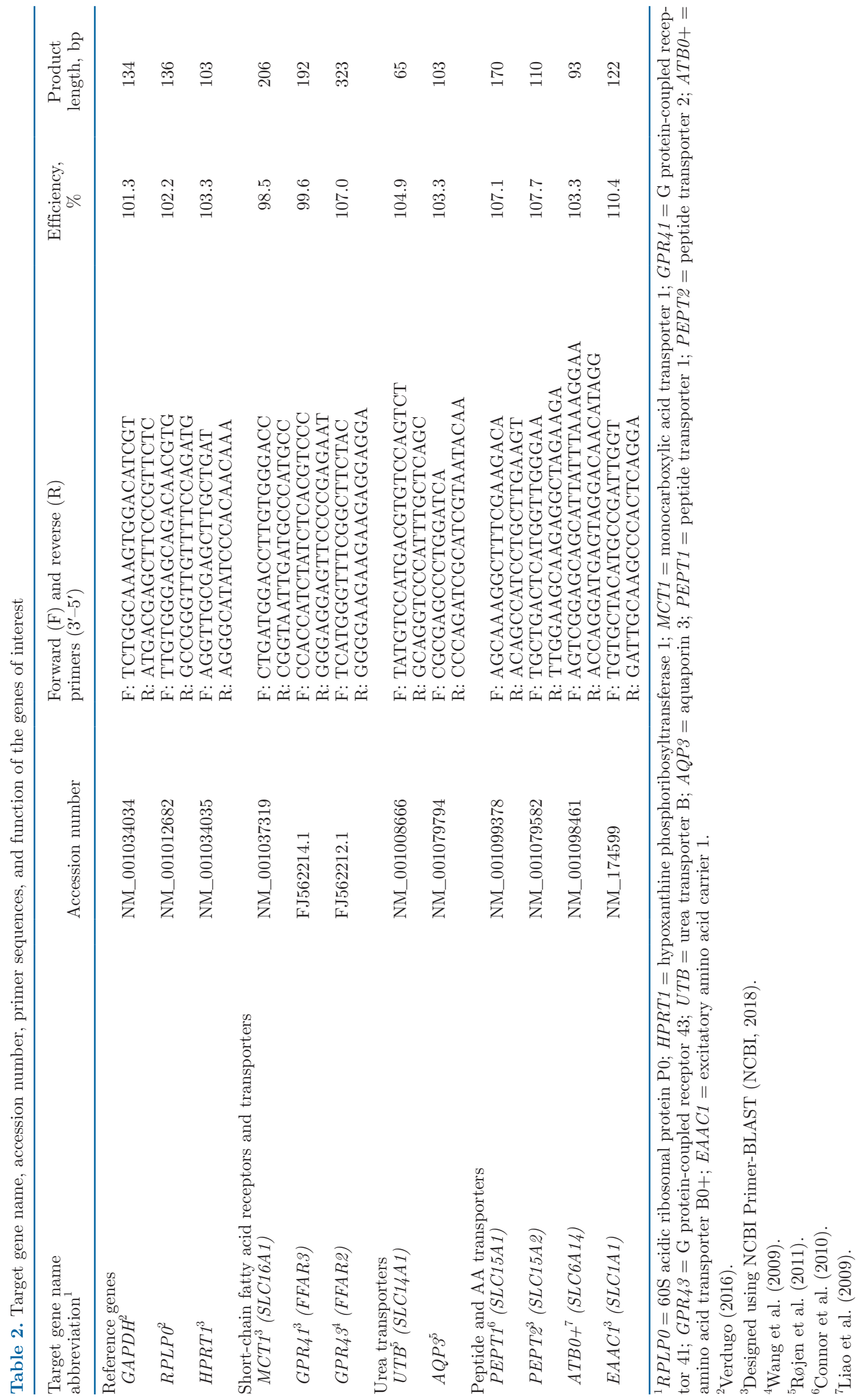


and L-leucyl-p-nitroanilide (Bachem, Budendorf, Sweden) were, respectively, used as substrates for analysis of aminopeptidase $\mathrm{A}$ and $\mathrm{N}$ activities (Maroux et al., 1973) and L-glycyl-p-nitroanilide (Bachem) was the substrate for dipeptidase IV activity (Nagatsu et al., 1976). The reaction was carried out in glass cuvettes and absorbance was measured using spectrophotometer at $410 \mathrm{~nm}$ for $10 \mathrm{~min}$ (Beckman Coulter, Brea, CA) fitted with a connection to a circulating water bath (1130-1S, VWR International, Mississauga, ON) to ensure stable reaction temperature. Brush border enzyme activities were calculated based on the amount of released product over the reaction period, either glucose for lactase and maltase or $p$-nitroanilidine for aminopeptidase A and N, and for dipeptidase IV. Enzyme activity was normalized per unit of protein in the tissue homogenate and 1 min of reaction.

\section{Statistical Analysis}

Optimal Heat-Treatment Temperature. Degradation rates were initially analyzed using the PROC NLIN of SAS (ver. 9.4, SAS Institute, Cary, NC) following Ørscov's model (Ørskov and McDonald, 1979) with the equation

$$
R(t)=U+D \times e^{-K_{d} \times\left(t-T_{0}\right)},
$$

where $R(t)$ is the percentage of residue at a given incubation time point $(t), U$ is the undegradable fraction $(\%), D$ is the potentially degradable fraction (\%), $e$ is Euler's number, $K_{d}$ is the degradation rate of $D(\% / \mathrm{h})$, and $T_{0}$ is lag time (h). Effective degradability was calculated following the equation

$$
E D=S+\frac{\left(D \times K_{d}\right)}{K_{d}+K_{p}}
$$

where $E D$ is the effective degradability, $S$ is the soluble fraction, which was washed out from 0 -h incubation bags, and $K_{p}$ is the rate of passage (assumed $K_{p}=$ $5 \% / \mathrm{h})$.

The effect of CM heat treatment on degradation rates for DM and CP, the degradable fractions, the effective degradability, and the estimated intestinal digestibility were analyzed using the mixed model in SAS version 9.4, considering heat treatment as the fixed effect with polynomial contrasts used to determine the linear or quadratic effect of heat treatment. Significance was declared when $P \leq 0.05$ and tendencies when $0.05<$ $P \leq 0.10$.
Effect of Heat-Treated CM and Glycerol on Calves. Data were analyzed as a randomized complete block design with a $2 \times 2$ factorial design using the mixed model of SAS. The model included the fixed effects of CM heat treatment (untreated and heated), glycerol inclusion (0 and 5\%), and the 2-way interaction. Block was considered as a random effect. Data were tested to verify whether the data and residuals were normally distributed and homoscedastic. Data that were collected over time (BW, ADG, starter intake, and milk replacer intake) were also analyzed using repeated measures with time (week or day) as a fixed effect and the relevant 2- and 3-way interactions. Covariance error structures were tested and the error structure for each variable with the least Akaike's and Bayesian Information Criterion was chosen. In case of a significant interaction between fixed effects, the Bonferroni mean separation was used to determine if treatment means differed. Differences were declared significant when $P$ $\leq 0.05$, and tendencies were declared when $P \leq 0.10$. As there were no interactions (2- or 3 -way) of treatment with time, only the main treatment effects and the interaction among the heat treatment and glycerol inclusion are reported.

\section{RESULTS}

\section{Study 1: Optimal Heat-Treatment Temperature for CM}

Increasing the temperature for the heat treatment of CM increased DM concentration at a decreasing rate (quadratic, $P=0.001$; Table 3), decreased OM concentration at a decreasing rate (quadratic, $P=0.002$ ), increased $\mathrm{CP}$ concentration at a decreasing rate (quadratic, $P=0.002)$, increased NDF and ADF concentrations at an increasing rate (quadratic, $P<0.001$ ), and increased ether extract concentration linearly $(P$ $=0.006)$. The increases in $\mathrm{CP}, \mathrm{NDF}, \mathrm{ADF}$, and ether extract were offset by a quadratic reduction in NFC concentration with the rate of reduction increasing as the temperature of heat treatment for CM increased $(P$ $<0.001)$.

The rate of DM disappearance from the rumen decreased at a decreasing rate with the increase of heattreatment temperature for $\mathrm{CM}$ (quadratic, $P=0.017$; Table 3). The soluble fraction of DM decreased at a decreasing rate (quadratic, $P=0.024$ ). The degradable fraction of DM decreased at an increasing rate with the increase of temperature (quadratic, $P<0.001$ ), with values of $60.0 \%$ for CON and $34.1 \%$ for H-120. The undegraded fraction of DM increased at an increasing rate (quadratic, $P<0.001$ ) with values of $14.1 \%$ for $\mathrm{CON}$ 
Table 3. Chemical composition and digestion characteristics of the nonheated (CON) and heat-treated canola meal when heated to achieve temperatures of $100(\mathrm{H}-100), 110(\mathrm{H}-110)$, or $120^{\circ} \mathrm{C}(\mathrm{H}-120)$ for $10 \min (\mathrm{n}=3)$

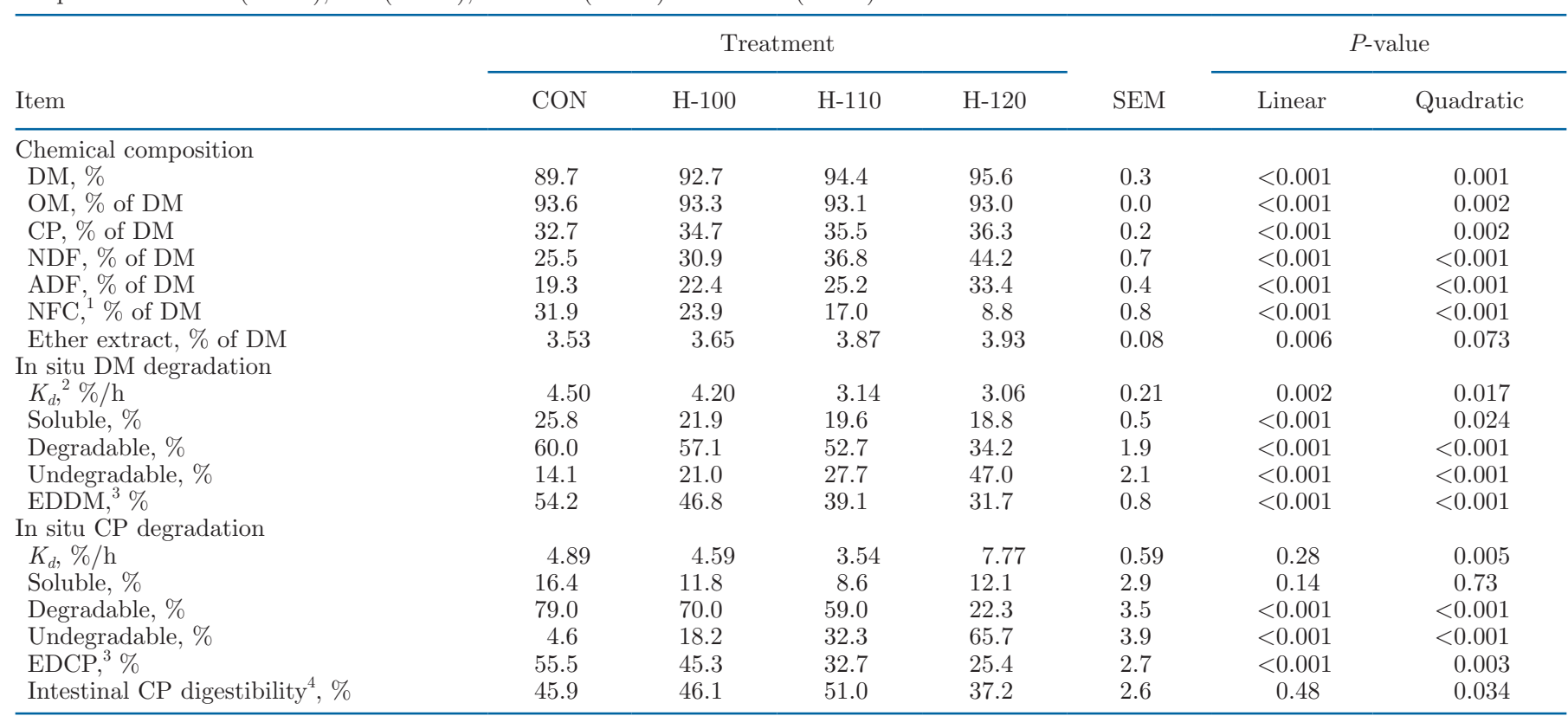

${ }^{1}$ NFC calculated based on NRC (2001): $100-(\mathrm{NDF}, \%+\mathrm{CP}, \%+$ ether extract, $\%+$ ash, $\%)$.

${ }^{2} K_{d}=$ the degradation rate of degradable fraction.

${ }^{3} \mathrm{EDDM}$ or $\mathrm{EDCP}=$ effectively degradable $\mathrm{DM}$ or $\mathrm{CP}$ assuming a $5 \% / \mathrm{h}$ passage rate.

${ }^{4}$ Estimated CP intestinal digestibility was based on a 3-step procedure described by Calsamiglia and Stern (1995).

and $47.0 \%$ for $\mathrm{H}-120$. The effectively degradable DM, assuming a constant passage rate of $5 \% / \mathrm{h}$, decreased at an increasing rate with increasing temperature of treatment (quadratic, $P<0.001$ ) from 54.2 for $\mathrm{CON}$ to $31.7 \%$ for $\mathrm{H}-120$. The rate of $\mathrm{CP}$ disappearance from the rumen decreased from CON $(4.89 \% / \mathrm{h})$ to $\mathrm{H}-110$ $(3.54 \% / \mathrm{h})$ and increased for $\mathrm{H}-120(7.77 \% / \mathrm{h}$; quadratic, $P=0.005)$. The soluble fraction of $\mathrm{CP}$ was not affected by heat treatment $(P \geq 0.14)$. The degradable fraction of $\mathrm{CP}$ decreased at an increasing rate when exposed to greater treatment temperatures (quadratic, $P<0.001$ ) with values ranging from 79.0 and $22.3 \%$ for CON and $\mathrm{H}-120$ treatments, respectively, and the $\mathrm{CP}$ undegraded fraction increased at an increasing rate (quadratic, $P<$ 0.001). The effectively degradable CP decreased at an increasing rate after exposure to increasing heat-treatment temperatures (quadratic, $P=0.003$ ) from $55.5 \%$ for $\mathrm{CON}$ to $25.4 \%$ for $\mathrm{H}-120$. The estimated intestinal digestibility responded quadratically to the increase of heat-treatment temperature $(P=0.034)$, with digestibility increasing from CON (45.9\%) to H-110 (51.0\%) and decreasing for $\mathrm{H}-120$ (37.2\%).

With increased heat-treatment temperature of CM, linear decreases in the concentration of $\operatorname{Arg}(P=0.002$; Table 4$)$, His $(P=0.003)$, Met $(P=0.048)$, Asp $(P=$ $0.026)$, Cys $(P=0.001)$, Glu $(P=0.035)$, Pro $(P=$ $0.043)$, and Ser $(P=0.049)$ were detected. In addition,
Lys $(P=0.059)$, Phe $(P=0.058)$, Thr $(P=0.099)$, and Val $(P=0.088)$ concentrations tended to decrease linearly. Isoleucine, Leu, Ala, and Gly concentrations were not affected by the heat treatment $(P \geq 0.101)$.

\section{Study 2: Effect of Heat-Treated CM and Glycerol on Calves}

Even though our treatment diets were designed to be isonitrogenous and could not be statistically evaluated, we observed numerically greater $\mathrm{CP}$ content in the heat-treated treatment diets (Table 1). Treatments that contained glycerol had numerically less starch and greater NSC concentration. There were no 2- or 3-way interactions of treatments with time for BW, ADG, starter intake, and milk replacer intake $(P \geq 0.21$, data not shown). The aforementioned variables increased with time $(P \leq 0.001$, data not shown $)$; however, these observations were expected for growing calves.

Initial and average BW of calves $(P \geq 0.47$; Table $5)$ were not affected by $\mathrm{CM}$ heat treatment. Heat treatment of CM decreased final BW $(P=0.041)$ and tended to reduce ADG $(P=0.079)$ and total BW gain $(P=0.097)$. When comparing starters without glycerol to those with glycerol, glycerol inclusion tended to increase $\mathrm{ADG}(P=0.088)$ and increased total BW gain $(P=0.003)$. Heat treatment of $\mathrm{CM}$ in the starter 
Table 4. Amino acid composition of nonheated (CON) and heat-treated canola meal when heated to achieve temperatures of 100 (H-100), 110 $(\mathrm{H}-110)$, or $120^{\circ} \mathrm{C}(\mathrm{H}-120)$ for $10 \min (\mathrm{n}=3)$

\begin{tabular}{|c|c|c|c|c|c|c|c|}
\hline $\mathrm{AA}$ & \multicolumn{4}{|c|}{ Treatment } & SEM & \multicolumn{2}{|c|}{$P$-value } \\
\hline \multicolumn{8}{|c|}{$\mathrm{EAA}, \%$ of $\mathrm{CP}$} \\
\hline Arg & 6.19 & 5.89 & 5.74 & 5.58 & 0.09 & 0.002 & 0.11 \\
\hline His & 2.72 & 2.62 & 2.52 & 2.52 & 0.04 & 0.003 & 0.27 \\
\hline Ile & 4.17 & 4.07 & 3.63 & 3.97 & 0.14 & 0.11 & 0.88 \\
\hline Leu & 7.30 & 7.12 & 6.95 & 6.78 & 0.17 & 0.101 & 0.72 \\
\hline Phe & 4.25 & 4.11 & 3.94 & 4.02 & 0.09 & 0.058 & 0.73 \\
\hline Thr & 4.56 & 4.46 & 4.33 & 4.24 & 0.11 & 0.099 & 0.63 \\
\hline Val & 5.36 & 5.18 & 5.00 & 5.09 & 0.12 & 0.088 & 0.83 \\
\hline \multicolumn{8}{|c|}{ NEAA, $\%$ of $\mathrm{CP}$} \\
\hline Ala & 4.66 & 4.55 & 4.34 & 4.43 & 0.11 & 0.104 & 0.69 \\
\hline Asp & 7.31 & 7.10 & 6.78 & 6.83 & 0.14 & 0.026 & 0.37 \\
\hline Cys & 2.45 & 2.32 & 2.25 & 2.25 & 0.03 & 0.001 & 0.40 \\
\hline
\end{tabular}

did not affect starter intake, with the exception of a tendency for reduced starter intake $(P=0.090)$ from d 43 to 49 - a time when milk replacer provision was limited to $2.5 \%$ of BW. Inclusion of glycerol tended to increase starter intake from d 29 to $35(P=0.056), \mathrm{d}$ 36 to $42(P=0.087)$, d 43 to $49(P=0.087)$, and the cumulative starter intake throughout the study $(P=$ 0.069). Milk replacer intake did not differ among treatments $(P \geq 0.14)$

We observed a tendency for a heat treatment $\times$ glycerol interaction for ruminal $\mathrm{pH}(P=0.070$; Table 5$)$ with the numerically greatest $\mathrm{pH}$ for the $\mathrm{H}-\mathrm{NG}$ treatment, intermediate for the NH-NG and NH-G treatments, and the least for the H-G treatment. Heat treatment of CM did not affect ruminal SCFA concentration $(P=0.11)$, but glycerol inclusion increased SCFA concentration $(P=0.005)$. There was a tendency for an interaction between heat treatment of $\mathrm{CM}$ and glycerol inclusion for the molar proportions of acetate and propionate $(P=0.075$ and $P=0.069$, respectively). In general, the greatest molar proportion of acetate was observed for the NH-NG treatment, intermediate for the $\mathrm{H}-\mathrm{G}$ treatment, and the least for the H-NG and NH-G treatments. The molar proportion of propionate was the greatest for the $\mathrm{NH}-\mathrm{G}$ treatment, intermediate for the H-NG treatment, and H-G treatment, and the least for the NH-NG treatment. Glycerol inclusion tended to decrease the molar proportions of iso-butyrate $(P=$ 0.092); however, the molar proportion of iso-butyrate was not affected by heat treatment $(P=0.43)$. The molar proportion of butyrate was not affected by the glycerol supplementation $(P=0.62)$, but tended to be greater when heat-treated canola was included in the starters $(P=0.100)$. The molar proportion of isovalerate tended to be decreased by the glycerol supplementation $(P=0.076)$. A heat treatment $\times$ glycerol interaction was observed for valerate $(P=0.041)$, but means that differed could not be detected with the Bonferroni posthoc analysis. The molar proportion of caproate and the ammonia concentration were not affected by the experimental treatments $(P \geq 0.25)$.

The weight of the ruminal tissue and ruminal digesta were reduced $(P \leq 0.011$; Table 6$)$ for calves fed heat-treated $\mathrm{CM}$ compared with those fed $\mathrm{CM}$ without additional heat treatment. Glycerol inclusion in the starter did not affect the weight of the ruminal tissue or digesta $(P \geq 0.18)$. Omasal tissue and digesta, and abomasal tissue weights were not affected by the experimental treatments $(P \geq 0.14)$. Abomasal digesta weight tended to be greater with glycerol supplementation $(P=0.080)$. Duodenal tissue weight and length were not affected by experimental treatments $(P \geq$ $0.15)$, and digesta weight tended to be greater with glycerol supplementation $(P=0.087)$. Jejunal tissue weight was less with heat treatment $(P=0.024)$ and tended to be greater with glycerol supplementation $(P=0.079)$. Glycerol supplementation also increased jejunal digesta weight $(P=0.001)$. Heat treatment of CM tended to decrease the jejunal length $(P=0.075)$. Ileal tissue weight and length were not affected by the experimental treatments $(P \geq 0.23)$. Heat treatment of CM decreased ileal digesta weight $(P=0.004)$. Cecal tissue weight and length were not affected by the experimental treatments $(P \geq 0.26)$. The $\mathrm{CM}$ heat treatment decreased cecal digesta weight $(P=0.018)$ and glycerol supplementation increased it $(P=0.009)$. A treatment 
Burakowska et al.: HEAT-TREATED CANOLA MEAL AND GLYCEROL INCLUSION

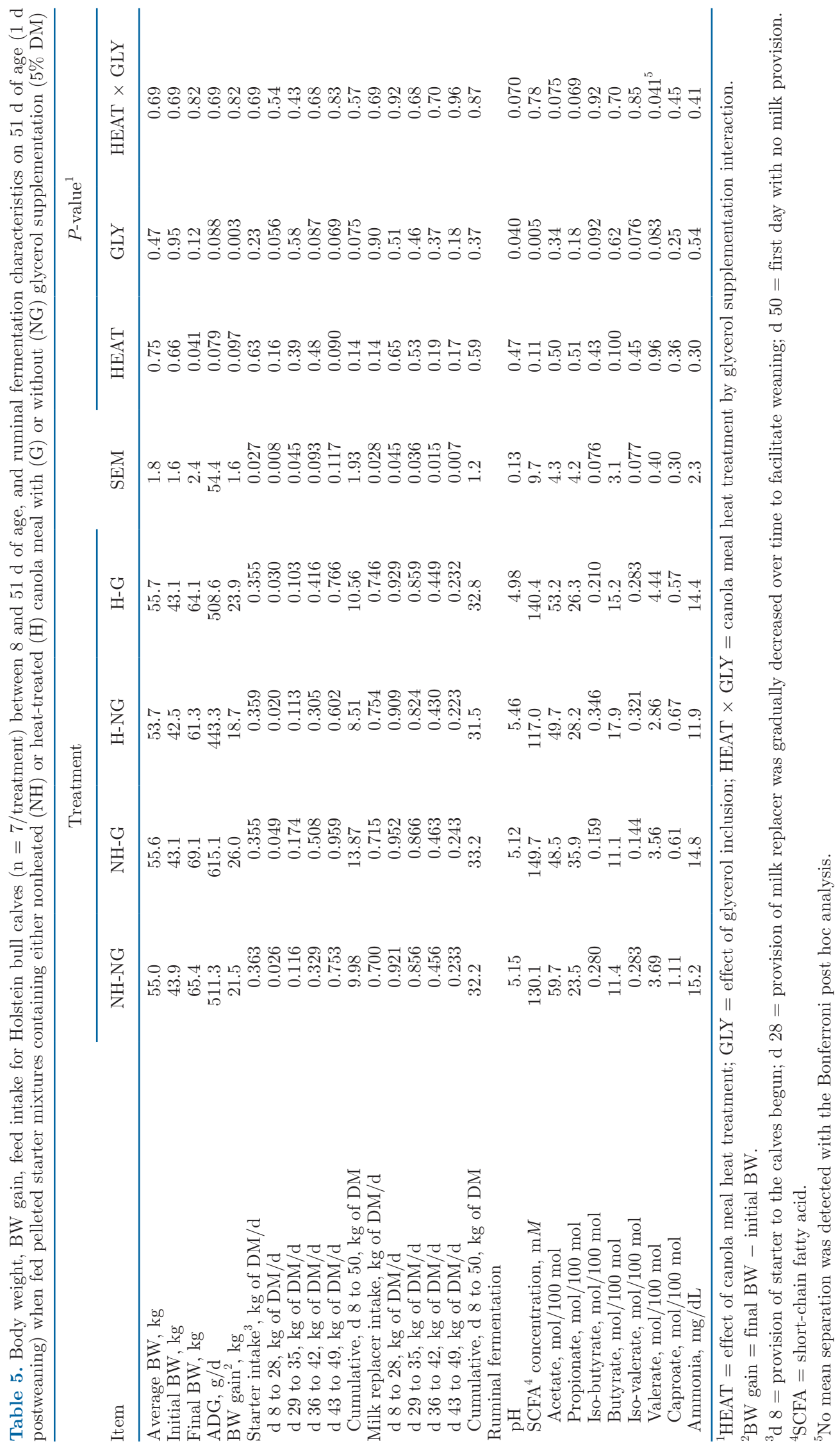


interaction was observed for the colonic length $(P=$ 0.038 ) and tended to be observed for colonic tissue weight $(P=0.099)$. Colonic length was the greatest for NH-NG treatment, intermediate for $\mathrm{NH}-\mathrm{G}$ and $\mathrm{H}-\mathrm{G}$, and shortest for H-NG treatment. Colonic tissue weight was numerically the greatest for the $\mathrm{H}-\mathrm{G}$ treatment, intermediate for NH-G and NH-NG treatments, and the least for $\mathrm{H}-\mathrm{NG}$ treatment. Colonic tissue weight also tended to be increased by the glycerol supplementation $(P=0.072)$, and colonic length was decreased by $\mathrm{CM}$ heat treatment $(P=0.010)$. Colonic digesta was not affected by the experimental treatments $(P \geq 0.13)$.

Heat treatment did not affect the gene expression of any of the analyzed genes of interest $(P \geq 0.22$; Table $7)$. A heat treatment $\times$ glycerol interaction was observed for AQP3 $(P=0.021)$ and tended to be observed for the expression of $\operatorname{MCT1}(P=0.076)$ in ruminal epithelium from the cranial sac. For the expression of $A Q P 3$, the Bonferroni mean separation test did not identify means that differed, but numerically the greatest expression of $A Q P 3$ was for the $\mathrm{H}-\mathrm{NG}$ treatment, followed by NH-G and NH-NG treatments, and the least for the H-G treatment. The expression of MCT1 was numerically greatest for the H-NG treatment, intermediate for the NH-NG and NH-G treatments, and the least for the $\mathrm{H}-\mathrm{G}$ treatment. Expression of UTB, GPR 41, and GPR 43 in the ruminal epithelium was not affected by the glycerol inclusion $(P \geq 0.26)$. Glycerol inclusion resulted in greater expression of MCT1 $(P=$ 0.017) in the epithelium of the PROX. A tendency for a heat treatment $\times$ glycerol supplementation interaction was observed for the expression of GPR 41 in the PROX $(P=0.089)$. Glycerol did not affect any of the genes of interest in the ileal epithelium $(P \geq 0.46)$.

We did not detect any treatment interactions nor effect of heat treatment of $\mathrm{CM}$ on brush border enzyme activities $(P \geq 0.16$; Table 8$)$. Inclusion of glycerol did not affect activity of aminopeptidase A, aminopeptidase $\mathrm{N}$, lactase, or maltase $(P \geq 0.19)$, but tended to increase dipeptidase IV activity in the middle jejunum $(P=0.059)$.

Heat treatment of CM did not affect plasma glucose concentration $(P \geq 0.18$, Table 9$)$. Glycerol supplementation tended to decrease plasma glucose concentration on d 43 of age $(P=0.076)$, but had no effect on glucose concentration on $\mathrm{d} 22$ and 51 of age $(P \geq$ 0.45). Plasma insulin concentration did not differ between the heat-treated and nonheated CM $(P \geq 0.27)$. On d 22 and 43 of age, plasma insulin was decreased by the glycerol supplementation $(P=0.016$ and $P$ $=0.003$, respectively). We observed a tendency for a heat treatment by glycerol supplementation interaction for plasma insulin concentration on d 51 of age $(P=$ 0.099), with the numerically greatest concentration for the both NH-G and H-NG treatments relative to NHNG and H-G. Serum BHB concentration on d 22 of age tended to be reduced with heat treatment $(P=$ 0.096), yet on d 43, BHB concentration was increased by heat treatment $(P=0.022)$. On $\mathrm{d} 51$ of age, serum BHB tended to be decreased by glycerol supplementation $(P=0.061)$. Plasma NEFA concentration was not affected by the experimental treatments on d 22 and 51 of age $(P \geq 0.23)$. On d 43 , plasma NEFA concentration tended to be less for calves fed heat-treated CM $(P=0.072)$ and tended to be less for glycerol inclusion $(P=0.092)$. A heat treatment $\times$ glycerol supplementation interaction was observed for plasma urea-N at 43 d of age $(P=0.035)$. Mean separation for this variable was not achieved; however, the greatest plasma urea-N concentration was observed for the NH-NG and $\mathrm{H}-\mathrm{G}$ treatments, intermediate for H-NG and the least for the $\mathrm{NH}-\mathrm{G}$ treatment. The main effects of heat treatment and glycerol inclusion did not affect plasma urea-N concentration on any of the $3 \mathrm{~d}$ of sample collection $(P$ $\geq 0.13)$

\section{DISCUSSION}

\section{Optimal Temperature for Heat Treatment of CM}

As CM is a byproduct from the canola crushing industry, processing conditions imposed within and among processing plants affect composition, especially for RDP and RUP proportions (Bell and Keith, 1991). The CON CM in the present study had similar proportions of the undegradable protein fraction as those reported by Huang et al. (2015) and Maxin et al. (2013). Moreover, we observed that heat treating CM increased the proportion of RUP, an observation reported previously (McKinnon et al., 1991; Dakowski et al., 1996). Though the intent of the heat treatment in the present study was to increase the rumen undegradable fraction, the heat-treating process also increased the NDF and ADF content, as observed in previous research (McKinnon et al., 1995). The increase in NDF and RUP was likely partially due to the Maillard reaction (van Soest and Mason, 1991), which is when soluble carbohydrate components react with AA to form indigestible compounds that are insoluble in neutral detergent solution. The latter statement is supported by the general reduction in AA concentrations observed with increasing heat treatment. Similar observations for decreased essential AA concentrations due to the Maillard reaction have been made by Ajandouz and Puigserver (1999); although, their treatments occurred in aqueous conditions. Past studies have also reported no effect of heat treatment on the CP content of CM (McKinnon et al., 1991, 1995; Dakowski et al., 1996). Conversely, we ob- 


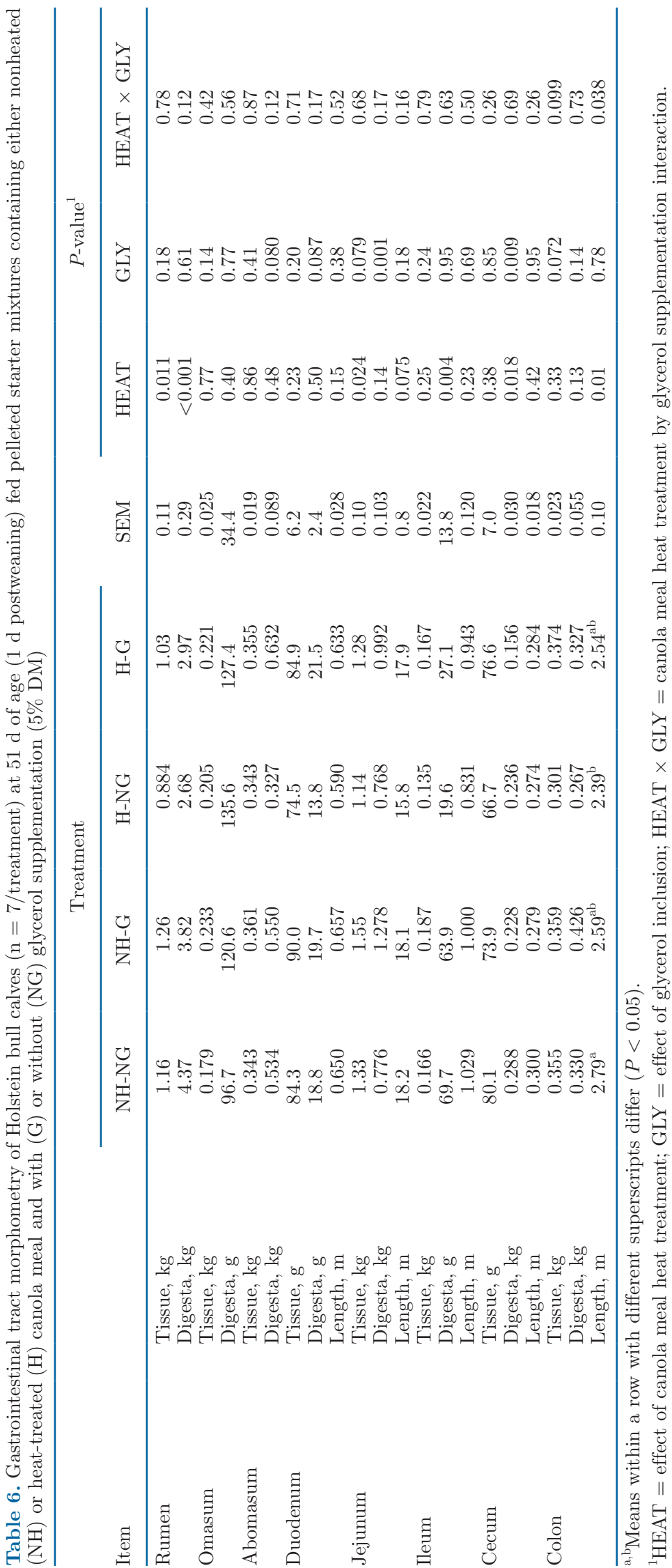


Table 7. Gene expression in the cranial sac of the rumen (CRA), proximal jejunum (PROX), and ileum (ILE) of Holstein bull calves ( $\mathrm{n}=7 /$ treatment) at $51 \mathrm{~d}$ of age $(1 \mathrm{~d}$ postweaning) as influenced by feeding pelleted starter mixtures containing either nonheated (NH) or heat-treated $(\mathrm{H})$ canola meal and with $(\mathrm{G})$ or without $(\mathrm{NG})$ glycerol supplementation $(5 \% \mathrm{DM})$

\begin{tabular}{|c|c|c|c|c|c|c|c|c|c|}
\hline \multicolumn{2}{|c|}{ Gene of interest ${ }^{1}$} & \multicolumn{4}{|c|}{ Treatment } & SEM & \multicolumn{3}{|c|}{$P$-value ${ }^{2}$} \\
\hline \multirow[t]{4}{*}{ CRA } & $M C T 1$ & $1.79^{3}$ & 1.84 & 1.70 & 2.18 & 0.13 & 0.30 & 0.034 & 0.076 \\
\hline & $A Q P 3$ & 0.492 & 0.303 & 0.237 & 0.753 & 0.164 & 0.49 & 0.26 & $0.021^{4}$ \\
\hline & $G P R_{4} 1$ & 15.2 & 15.3 & 15.0 & 14.5 & 0.4 & 0.29 & 0.64 & 0.50 \\
\hline & GPR43 & 14.1 & 14.5 & 14.0 & 13.7 & 0.4 & 0.22 & 0.95 & 0.33 \\
\hline \multirow{4}{*}{ PROX } & $E A A C 1$ & 7.73 & 8.39 & 8.33 & 7.92 & 0.38 & 0.85 & 0.73 & 0.15 \\
\hline & $A T B O+$ & 4.15 & 4.03 & 3.72 & 4.18 & 0.24 & 0.48 & 0.39 & 0.16 \\
\hline & $G P R 41$ & 9.33 & 9.55 & 9.52 & 9.29 & 0.12 & 0.81 & 0.95 & 0.089 \\
\hline & GPR43 & 9.30 & 9.18 & 9.00 & 8.98 & 0.23 & 0.28 & 0.76 & 0.83 \\
\hline \multirow[t]{2}{*}{ ILE } & MCT1 & 6.66 & 6.57 & 6.57 & 6.77 & 0.21 & 0.63 & 0.63 & 0.22 \\
\hline & PEPT1 & 6.02 & 5.96 & 5.83 & 6.11 & 0.32 & 0.93 & 0.73 & 0.59 \\
\hline
\end{tabular}

${ }^{1} M C T 1=$ monocarboxylic acid transporter $1 ; G P R 41=\mathrm{G}$ protein-coupled receptor $41 ; G P R 43=\mathrm{G}$-protein-coupled receptor $43 ; U T B=$ urea transporter $\mathrm{B} ; A Q P 3=$ aquaporin $3 ; P E P T 1=$ peptide transporter $1 ; P E P T 2=$ peptide transporter $2 ; A T B 0+=$ amino acid transporter $\mathrm{B} 0+$; $E A A C 1=$ excitatory amino acid carrier 1.

${ }^{2} \mathrm{HEAT}=$ effect of canola meal heat treatment; GLY $=$ effect of glycerol inclusion; $\mathrm{H} \times \mathrm{G}=$ canola meal heat treatment by glycerol supplementation interaction.

${ }^{3}$ Values of gene expression are presented as $\Delta \mathrm{C}_{\mathrm{T}}=$ threshold cycle $\left(\mathrm{C}_{\mathrm{T}}\right)$ for the gene of interest $-\mathrm{C}_{\mathrm{T}}$ for the reference genes; greater $\Delta \mathrm{C}_{\mathrm{T}}$ values represent lesser mRNA expression.

${ }^{4}$ No mean separation was detected with the Bonferroni post hoc analysis.

served that CP concentration increased at a decreasing rate with increasing heat-treatment temperature. It is unclear why $\mathrm{CP}$ concentration was altered with heat treatment.

As expected, heat treatment decreased the proportion of potentially degradable $\mathrm{CP}$ in the rumen, reduced the degradation rate of the degradable fraction $\left(K_{d}\right)$ relative to untreated CM, and quadratically decreased the estimated intestinal digestibility of CP. Heat treatment also decreased the concentration of Glu, a response that was opposite to that previously reported (Newkirk et al., 2003). It is unclear why results in the present study and that of Newkirk et al. (2003) differ, but may be related to the heat-treatment protocol and the inherent composition of the CM. The increase in the undegradable fraction and stimulatory effect of heat treatment on intestinal CP digestibility indicate that we achieved an increase the RUP without having marked reductions in the intestinal digestibility with our approach. Although we measured in situ degradation using heifers, rather than calves, Vazquez-Anon et al. (1993) suggested that measurements made with cows may reasonably approximate in situ digestion in calves within 4 wk of weaning. Other studies have also suggested that ruminal fermentation at the time of weaning is not dif- ferent from that occurring several weeks after weaning (Quigley et al., 1985; Lallès and Poncet, 1990).

\section{Interactions Between CM Heat Treatment and Glycerol Supplementation}

When designing the current study, we anticipated interactions among heat-treated CM and glycerol inclusion in starters because glycerol inclusion could increase the concentration of ruminal butyrate (Rémond et al., 1993; Paiva et al., 2016) and potentially stimulate ruminal development (Sander et al., 1959; Mentschel et al., 2001), whereas heat-treated CM could increase the supply of AA to the intestine, potentially promoting intestinal growth and functions. Altogether, feed intake and calf performance could be enhanced. However, only a few interactions were observed and the detected interactions were primarily only tendencies. It is unclear why the interactions did not occur, but a possible explanation is that heat treatment of CM may have reduced apparent total-tract $\mathrm{CP}$ digestibility, thereby limiting one of the potential synergistic effects. This previous explanation is partially supported by reduced BW gain with heat-treated CM; however, we did not measure apparent total-tract digestibility and cannot 


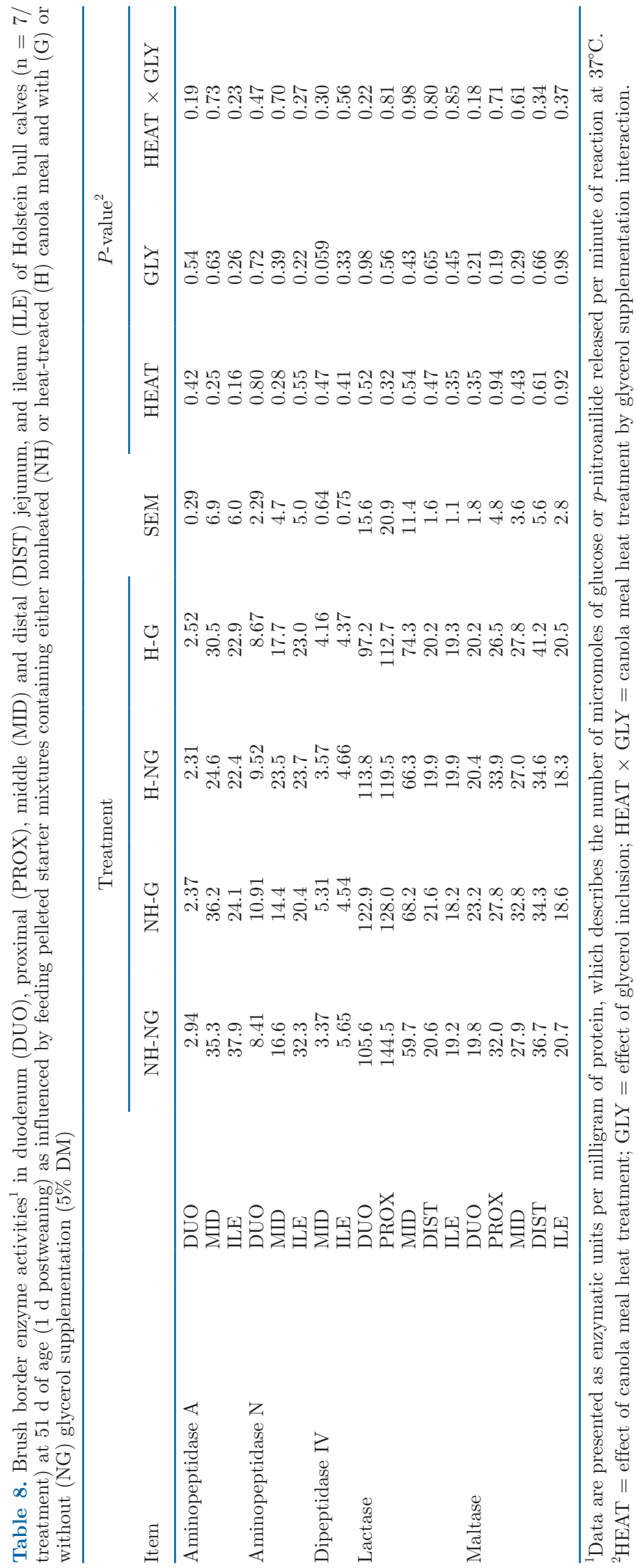




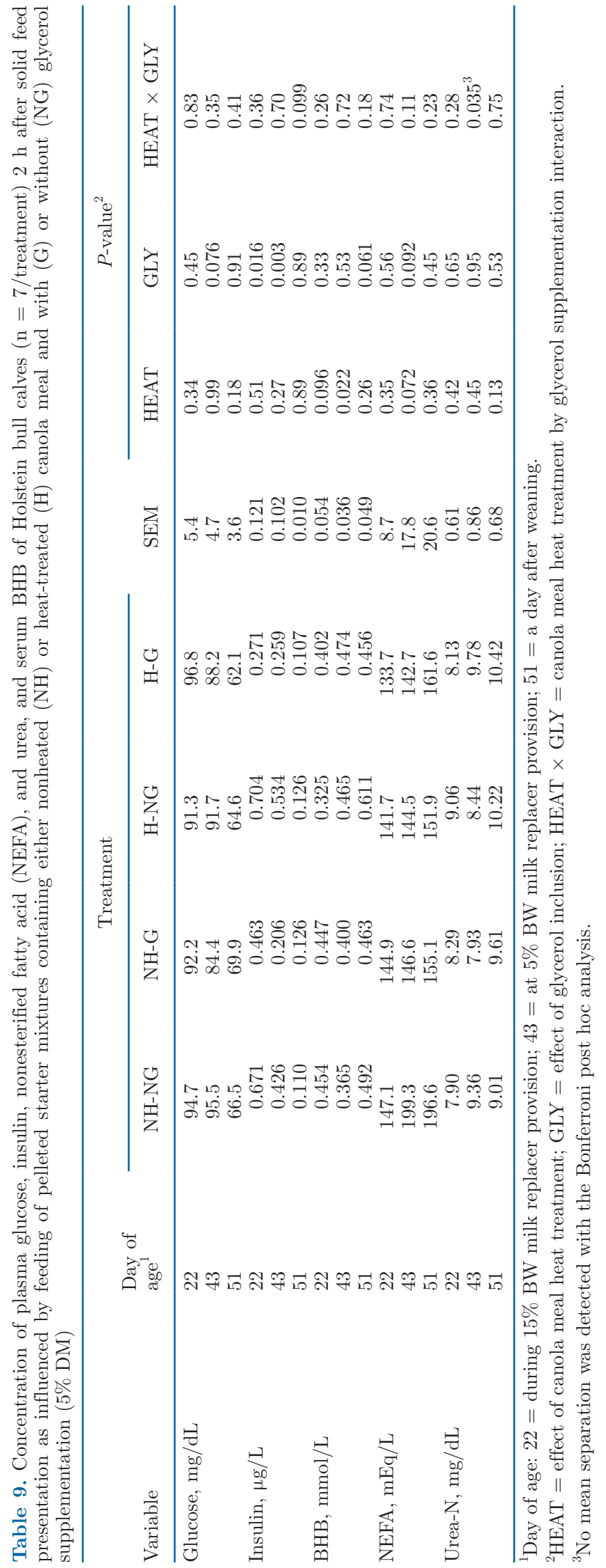

confirm the digestibility response. Others have also reported that heat-treatment of protein sources (soybean meal) for calves did not alter the intestinal supply of protein from microbial protein or RUP, despite the reduction of effective ruminal degradability measured in in situ in a steer from heat treatment (Obitsu et al., 1995). Additionally, glycerol did not increase ruminal butyrate concentration in the present study, and hence the secondary proposed mode of action for beneficial effects of heat-treated CM and glycerol inclusion was not observed. As such, the main effects of heat-treated $\mathrm{CM}$ and glycerol will be discussed separately and the most important interactions will be mentioned and discussed.

\section{Effect of Heat-Treating CM on Calf Performance and Development of the GIT}

Studies have evaluated the use of CM in starter mixtures for calves, suggesting that use of CM may decrease starter intake (Stake et al., 1973; Miller-Cushon et al., 2014b), CP digestibility (Schingoeth et al., 1974; Fiems et al., 1985; Khorasani et al., 1990), and ADG (MillerCushon et al., 2014b; Hadam et al., 2016) relative to soybean meal; however, in some studies starter intake (Ingalls and Seale, 1971; Fisher, 1980), CP digestibility (Stake et al., 1973; Fisher, 1980), and ADG (Stake et al., 1973; Fisher, 1980; Fiems et al., 1985) were not affected by protein source. In the present study, we did not compare different protein sources, but compared untreated and heat-treated CM to evaluate the effect of altering the RUP supply.

In the current study, we observed decreased ADG and, as a result, a lighter final BW when calves were fed starters containing heat-treated CM. Calves fed heat-treated $\mathrm{CM}$ tended to have less cumulative starter intake from d 8 to 50; of which the most notable response was from d 43 to 49 . In the 2 studies reported by Obitsu et al. (1995), feeding calves heat-treated soybean meal did not affect DMI when compared with soybean meal that was not heated, but calves in those studies received 30 or $40 \%$ of their diet as hay, which may have masked treatment effects. In the present study, calves that ate diets containing heat-treated $\mathrm{CM}$ also had lighter reticulo-ruminal and jejunal weights. Given the importance of the reticulo-rumen for fermentation of feed and SCFA absorption, and the importance of the jejunum to facilitate protein digestion and absorption, the reduction in tissue weights could indicate decreased digestive capacity. Additionally, ruminal, ileal, and cecal digesta weights were lighter for the heat-treated CM treatment, likely reflecting a smaller gastrointestinal tract size and the tendency for lesser DMI. However, the effect appears to be influenced primarily by the 
changes in tissue weight as gene expression and brush border enzyme activities were, in general, not affected by heat treatment.

A critical assumption in this study was that a large portion of the RUP from heat-treated CM could be digested in the small intestine, as indicated by the in vitro measurement approach employed. However, the lack of a positive effect of heat treatment may be indicative of reduced $\mathrm{CP}$ digestibility with heat treatment, thereby eliminating potential increases for the total metabolizable protein supply, or that provision of RUP may not provide added benefit for calves around weaning. Unfortunately, we did not confirm digestibility of the starters in vivo, and therefore cannot determine the cause for the lack of effect. Although we conclude that heat treatment of CM to increase the RUP was not effective, part of this response is attributed to the reduction in starter intake. Using simple predictions from the in situ degradability of CM in study 1 combined with starter intake and the composition of the starter in study 2, the RUP supply from CM can be estimated. As expected, until $35 \mathrm{~d}$ of age, CM provision in the starter was estimated to supply up to $5 \%$ of the total RUP. The low contribution of the CM in the starter toward the RUP supply were mostly due to the relatively small quantities of starter intake, large quantities of MR intake, and the assumption that the CP in milk replacer was 100\% RUP (data not shown). Comparatively, during the step-down weaning phase, the estimated contribution of CM to the supply of RUP ranged from 42.90 to $50.11 \%$, resulting in the predicted supply of 48 to $64 \mathrm{~g} / \mathrm{d}$. However, between 43 and $49 \mathrm{~d}$ of age, heat treatment of CM may have only marginally increased the supply of RUP from $54 \mathrm{~g} / \mathrm{d}$ for CM that was not heated to $57 \mathrm{~g} / \mathrm{d}$ for $\mathrm{CM}$ that was heated, again mostly due to the negative effect of heated CM on starter intake. Importantly, the predicted RUP contribution from CM in the starter increased the metabolizable protein supply from milk replacer by 75 to $100 \%$, showing that during the step-down phase of the weaning process, solid feed contributes substantially to the potential RUP supply. Even though these calculations are essential to approximate the contribution of the treatments to the RUP supply, they do not account for differences in the digestibility of the RUP fraction and rely on the use of in situ degradation measurements conducted in heifers to predict the response. Moreover, these calculations do not account for potential differences in the RUP supply with pelleting of the treatments (Huang et al., 2015) or other ingredients within the pellet, and rely on the assumption that capacity for ruminal digestion of $\mathrm{CP}$ in $\mathrm{CM}$ was similar to that for mature cattle. The latter suggestion is supported by previous research where ruminal SCFA concentrations and the contribution of bacterial $\mathrm{N}$ to the omasal $\mathrm{N}$ supply were not different during the week of weaning relative to that measured postweaning (Quigley et al., 1985). Additionally, the lining of the intestinal tissue can be renewed every 2 to $3.5 \mathrm{~d}$, depending on species (Darwich et al., 2014), which suggests that even short exposure to differing ration RUP fraction might have potential to influence the development of the intestine. With that said, there is a paucity of research evaluating the digestive capability of calves around weaning and how RUP affects metabolizable protein supply (Hill et al., 2013), especially when originating from heat treatment of a protein source (Vazquez-Anon et al., 1993).

Given the relatively high AA requirement for growing calves (NRC 2001), the dietary changes occurring during weaning, and that ruminal fermentation may not provide sufficient quantities microbial protein to meet metabolizable protein requirements, we hypothesized that providing additional RUP may enhance the growth of Holstein calves. However, use of plant-based proteins in milk replacer reduced digestibility (Guilloteau et al., 2011) and altered the intestinal epithelium (Górka et al., 2011); furthermore, cooking soy protein at $50^{\circ} \mathrm{C}$ overnight further reduced digestibility (Dawson et al., 1988). As such, we speculated that despite the limited effects of heat treatment on the estimated intestinal digestibility determined in vitro, heat treatment of CM may have decreased total-tract CP digestibility, thereby limiting AA supply to promote growth of the GIT and BW growth. The potential reduction in digestibility is further supported by Montagne et al. (2003), as they suggested that the digestion of plant-based protein might be limited at oligopeptide digestion and AA absorption steps in calves. On the contrary, Obitsu et al. (1995) reported that there were no differences in bacterial $\mathrm{N}$ flow to the intestine when calves were fed soybean meal or heated soybean meal, suggesting that rather than a reduction in digestibility of $\mathrm{CP}$, heat treatment may not have increased the flow of RUP. This latter suggestion is supported by the empirical calculations previously described. Given that we did not observe any changes in proteolytic brush border enzyme activity or gene expression for AA transporters, it may be postulated that intestinal digestibility was not improved or that intestinal supply of microbial $\mathrm{N}$ and the flow of RUP were not altered. Nevertheless, it is clear that heat treatment of $\mathrm{CM}$ does not stimulate growth or intestinal development in calves around weaning. Alternatively, it cannot be excluded that heat treatment of CM had a suppressive effect on rumen development, particularly ruminal fermentation development; however, ruminal $\mathrm{pH}$ and SCFA concentrations in calves were not affected by feeding them heat-treated CM, challenging such a hypothesis. Moreover, heat-treated 
$\mathrm{CM}$ did not affect rumen ammonia-N, suggesting that the RDP supply was adequate.

Heat treatment of CM had only small effects on the blood metabolites evaluated by decreasing BHB on d 22 and increasing BHB in d 43, as well as NEFA concentration on $\mathrm{d} 43$. The calves consuming heat-treated CM overall consumed less starter between d 8 and 28, which could result in the lesser BHB concentration on d 22. On the other hand, heat treatment of CM tended to result in increased ruminal butyrate proportion postweaning, which could result in the increased BHB concentration in the serum. The reason why heat treatment of CM increased ruminal butyrate is not clear.

\section{Effect of Glycerol on Calf Performance and Development of the GIT}

Calves that consumed starters supplemented with glycerol cumulatively consumed more starter during the whole study and especially during the step-down period. A possible reason for the increase in starter intake is that glycerol has been suggested to have a sweet taste (Quispe et al., 2013) and, therefore, may increase palatability of starter feed. However, a recent review has suggested that glycerol has relatively inconsistent effects on DMI, and the response is likely due to purity of the glycerol source and dose (Kholif, 2019). The glycerol used in the present study had greater than $80 \%$ purity and was included at a relatively low rate, supporting that glycerol may enhance DMI at low inclusions (Ariko et al., 2015).

As a result of greater starter intake, both ADG and total BW gain were greater in glycerol supplemented calves. In a study conducted on beef calves (309.3 \pm $14.0 \mathrm{~kg}$ ), ADG increased when glycerol was included at $10 \%$ of the DM and decreased when included at $20 \%$ (Ramos and Kerley, 2012); however, a following study within the same publication did not yield any changes in ADG. Pantophlet et al. (2016) also reported no effect of glycerol on growth of calves. Although calves used for the previous studies were older than the calves in the present study, there is evidence that, even with a low inclusion rate, glycerol might have positive effects on growth of young ruminants.

As expected, with rapid glycerol fermentation in the rumen (Rémond et al., 1993), ruminal SCFA concentration increased in calves fed glycerol supplemented starters, and as a consequence, a decrease in ruminal $\mathrm{pH}$ was noted. Similar effects have been previously observed in dairy cows (DeFrain et al., 2004; Mach et al., 2009); however, others have reported no changes for ruminal SCFA concentrations in calves (Ramos and Kerley, 2012) or cows (Paiva et al., 2016) when glycerol was included in the diet. According to Hall et al. (2015), SCFA concentration might not be the most reliable measure of fermentation, as it does not account for the ruminal volume, ruminal dilution, or absorption rates. The ruminal dilution rate may be particularly important in young calves (Yohe et al., 2018) considering that we observed increased digesta weight in the abomasum, duodenum, jejunum, and cecum, and increased tissue mass of the jejunum and colon when calves were supplemented with glycerol without differences in ruminal tissue weight. We suspect that glycerol might promote faster digesta passage through the GIT because glycerol increased starter intake, did not affect ruminal digesta weight, and increased digesta weight in regions of the GIT distal to the rumen. As a consequence, more nutrients were likely digested postruminally, as indicated by greater dipeptidase IV activity in jejunum, especially when glycerol was combined in the starter with heat-treated CM. Similar observations of increased dipeptidase IV activity in the distal jejunum were made when supplying microencapsulated sodium butyrate, another energy substrate, to calves (Górka et al., 2014). Along this line of thought, Werner Omazic et al. (2015) estimated that $25 \%$ of glycerol is fermented, $45 \%$ is absorbed, and $30 \%$ flows into the omasum of dairy cows; however, such data are not available for calves. Given the potential for ruminal fermentation in the present study and outflow from the reticulo-rumen, it is likely that some of the glycerol was fermented in the intestine, possibly promoting intestinal growth. Further support for this suggestion includes that the expression of MCT1 was upregulated in the jejunum, implying greater potential for SCFA absorption from the intestine for calves supplemented glycerol. Unfortunately, in the present study, we did not measure SCFA concentration in the small or large intestines, and thus cannot determine whether SCFA concentrations were altered. Nevertheless, SCFA released postruminally or delivered with digesta to lower regions of the GIT may have an important effect on GIT development in calves (Górka et al., 2018).

Werner Omazic et al. (2015) noted, as mentioned previously, that in addition to being fermented in the rumen and passing to the omasum, glycerol can be transported through the epithelium. Apparent transport of glycerol into portal circulation was observed both in mature dairy cows (Werner Omazic et al., 2015) and in calves (Werner Omazic et al., 2013), following a large pulse-dose of glycerol into the rumen. In the current study, we did not observe differences in the expression of AQP3 in the CRA due to glycerol, although we did observe a heat treatment by glycerol inclusion interaction. Aquaporin 3 is a water channel within the ruminal epithelium and is within a subgroup classified as aquaglyceroporins, as they are able to 
transport small particles such as urea (Rojek et al., 2008; Walpole et al., 2015) or glycerol (Wu and Beitz, 2007). It is possible that the dose of glycerol in the present study was not sufficient to stimulate a response for AQP3 expression or that the transport was mediated by other aquaglyceroporins such as $A Q P$ \%, $A Q P$, or $A Q P 10$ (Rojek et al., 2008) that were not analyzed in the present study.

Glycerol can modulate ruminal fermentation and has been reported to increase the molar proportion of propionate (Rémond et al., 1993; DeFrain et al., 2004; Ramos and Kerley, 2012) and butyrate (Rémond et al., 1993; DeFrain et al., 2004; Paiva et al., 2016) and decrease acetate (Rémond et al., 1993; Ramos and Kerley, 2012; Paiva et al., 2016). In the present study, we did not observe changes in the molar proportions of acetate, propionate, or butyrate with glycerol inclusion. Reasons for the discrepancy between the present study and past studies may be due to the single spot-sampling approach used in the present study compared with more frequent measurements in the previous studies, and that calves in the present study were transitioning to solid feed. Differences could also arise from a lower dose of glycerol in the present study (5\% DM). For example, Paiva et al. (2016) used glycerol inclusions ranging from 7 to $21 \%$ of DM, Ramos and Kerley (2012) used 0 to $20 \%$ DM, and Rémond et al. (1993) dosed ruminally cannulated cows at 20 or $40 \%$ of DM. However, DeFrain et al. (2004) used glycerol doses within a similar range as the current study with only very minor changes in SCFA concentration. Thus, in the current study, the positive effect of glycerol inclusion in starter mixture was likely not a result of its effect on ruminal butyrate, and thus stimulation of rumen epithelium development, which was originally hypothesized.

Glycerol decreased both plasma glucose and insulin concentrations on d 43-a time point corresponding to when calves were exposed to the step-down weaning process. The reduction in glucose and insulin might be due to the decrease in the starch supply in the glycerol treatments due to glycerol introduction into the feed. Similar observations for reduced glucose have been reported in mature ruminants when corn was replaced by glycerol (Carvalho et al., 2011). Surprisingly, glycerol also resulted in decreased NEFA concentration on $\mathrm{d}$ 43, further suggesting that the reduction in glucose and insulin were not driven by reduced nutrient intake. However, we observed lesser BHB concentration on d 51 for calves fed glycerol, suggesting that the potentially added nutrient supply was likely not mediated through butyrate as was observed by Carvalho et al. (2011). That said, glycerol increased both the total SCFA concentration in the rumen and starter intake during the step-down period and would be expected to increase, rather than decrease BHB (Quigley et al., 1991). There was also no effect of glycerol on tissue mass in the proximal parts of GIT, and therefore the decreased of BHB concentration is difficult to explain.

In the present study, calves fed starters with heattreated CM with glycerol had the greatest gene expression of MCT1 in the CRA and the least when fed heat-treated CM without glycerol. The gene MCT1 is a monocarboxylate transporter responsible for the removal of SCFA and ketones out of the rumen (Halestrap and Price, 1999). Nakamura et al. (2018) showed that $M C T 1$ was upregulated in postweaned calves, although MCT1 was not affected by changes in SCFA profiles. The increased MCT1 observed in the present study may be related to greater starter intake between d 29 and 50 of age, as calves supplemented with glycerol consumed more starter than calves not supplemented with glycerol. However, heat treatment increased ruminal butyrate, and butyrate is known to increase MCT1 expression in ruminal epithelium (Dengler et al., 2015).

\section{CONCLUSIONS}

Increasing heat-treatment temperature decreased the ruminally degradable DM and CP fractions in CM with minimal effects on estimated intestinal digestibility in cannulated heifers when heated at $110^{\circ} \mathrm{C}$ for $10 \mathrm{~min}$. Heat-treated CM and glycerol inclusion do not interact to promote development of the GIT in calves around weaning. Feeding heat-treated CM to calves before and during weaning transition may reduce ADG and GIT development. Inclusion of glycerol at 5\% DM may positively affect ADG. Furthermore, glycerol may increase ruminal fermentation and $M C T 1$ expression in the small intestine, suggesting stimulation of GIT development.

\section{ACKNOWLEDGMENTS}

The authors acknowledge the technical assistance of G. Gratton, K. Hare, F. Joy, R. Kanafany-Guzman, A. Laarman, R. Pederzolli, C. Rosser, A. Verdugo, D. Watanabe, and K. Wood (Department of Animal and Poultry Science, University of Saskatchewan, Saskatoon, SK, Canada). The authors acknowledge P. Yu and and Z. Niu (Department of Animal and Poultry Science, University of Saskatchewan) for their assistance with estimated intestinal digestibility assay. The authors also acknowledge Evonik Nutrition and Care GmbH (Essen, Germany) for their support with amino acid analysis. The authors thank D. Michel and B. Bandy from the Health Sciences Department at the University of Saskatchewan for providing access to their laboratory equipment. Funding for this project was provided by Saskatchewan Canola Development 
Commission (Saskatoon, SK, Canada), Saskatchewan Agriculture Development Fund (Regina, SK, Canada), Western Grains Research Foundation (Saskatoon, SK, Canada), and the Alberta Crop Industry Development Fund (Lacombe, AB, Canada). The authors have not stated any conflicts of interest.

\section{REFERENCES}

Ajandouz, E. H., and A. Puigserver. 1999. Nonenzymatic browning reaction of essential amino acids: Effect of $\mathrm{pH}$ on caramelization and Maillard reaction kinetics. J. Agric. Food Chem. 47:1786-1793. https://doi.org/10.1021/jf980928z.

AOAC International. 1994. Official Methods of Analysis of AOAC International. 16th ed. AOAC International, Arlington, VA.

AOAC International. 2000. Official Methods of Analysis of AOAC International. 17th ed. AOAC International, Gaithersburg, MD.

AOAC International. 2006. Official Methods of Analysis of AOAC International. 18th ed. AOAC International, Gaithersburg, MD.

Ariko, T., M. Kass, M. Henno, V. Fievez, O. Kärt, T. Kaart, and M. Ots. 2015. The effect of replacing barley with glycerol in the diet of dairy cows on rumen parameters and milk fatty acid profile. Anim. Feed Sci. Technol. 209:69-78. https://doi.org/10.1016/j.anifeedsci 2015.08.004

Bell, J. M., and M. O. Keith. 1991. A survey of variation in the chemical composition of commercial canola meal produced in western Canadian crushing plants. Can. J. Anim. Sci. 71:469-480. https:/ /doi.org/10.4141/cjas91-056.

Calsamiglia, S., and M. Stern. 1995. A three-step in vitro procedure for estimating intestinal digestion of protein in ruminants. J. Anim. Sci. 73:1459-1465. https://doi.org/10.2527/1995.7351459x.

Carvalho, E. R., N. S. Schmelz-Roberts, H. M. White, P. H. Doane, and S. S. Donkin. 2011. Replacing corn with glycerol in diets for transition dairy cows. J. Dairy Sci. 94:908-916. https://doi.org/10 $.3168 / \mathrm{jds} .2010-3581$.

Chomczynski, P., and N. Sacchi. 1987. Single-step method of RNA isolation by acid guanidinium thiocyanate-phenol-chloroform extraction. Anal. Biochem. 162:156-159. https://doi.org/10.1016/ 0003-2697(87)90021-2.

Claypool, D. W., C. H. Hoffman, J. E. Oldfield, and H. P. Adams. 1985. Canola meal, cottonseed, and soybean meals as protein supplements for calves. J. Dairy Sci. 68:67-70. https://doi.org/10 .3168/jds.S0022-0302(85)80798-0.

Connor, E. E., R. L. Baldwin, A. V. Capuco, C. M. Evock-Clover, S. E. Ellis, and K. S. Sciabica. 2010. Characterization of glucagonlike peptide 2 pathway member expression in bovine gastrointestinal tract. J. Dairy Sci. 93:5167-5178. https://doi.org/10.3168/ jds.2010-3205.

Dahlqvist, A. 1984. Assay of intestinal disaccharidases. Scand. J. Clin. Lab. Invest. 44:169-172. https://doi.org/10.3109/ 00365518409161400.

Dakowski, P., M. R. Weisbjerg, and T. Hvelplund. 1996. The effect of temperature during processing of rape seed meal on amino acid degradation in the rumen and digestion in the intestine. Anim. Feed Sci. Technol. 58:213-226. https://doi.org/10.1016/0377 -8401(95)00868-3.

Darwich, A. S., U. Aslam, D. M. Ashcroft, and A. Rostami-Hodjegan. 2014. Meta-analysis of the turnover of intestinal epithelia in preclinical animal species and humans. Drug Metab. Dispos. 42:20162022. https://doi.org/10.1124/dmd.114.058404.

Dawson, D. P., J. L. Morrill, P. G. Reddy, H. C. Minocha, and H. A. Ramsey. 1988. Soy protein concentrate and heated soy flours as protein sources in milk replacer for preruminant calves. J. Dairy Sci. 71:1301-1309. https://doi.org/10.3168/jds.S0022 $-0302(88) 79687-3$

DeFrain, J. M., A. R. Hippen, K. F. Kalscheur, and P. W. Jardon. 2004. Feeding glycerol to transition dairy cows: Effects on blood metabolites and lactation performance. J. Dairy Sci. 87:4195-4206. https://doi.org/10.3168/jds.S0022-0302(04)73564-X.
Dengler, F., R. Rackwitz, F. Benesch, H. Pfannkuche, and G. Gäbel. 2015. Both butyrate incubation and hypoxia upregulate genes involved in the ruminal transport of SCFA and their metabolites. J. Anim. Physiol. Anim. Nutr. (Berl.) 99:379-390. https://doi.org/ 10.1111/jpn.12201

DuBois, M., K. A. Gilles, J. K. Hamilton, P. A. Rebers, and F. Smith. 1956. Colorimetric method for determination of sugars and related substances. Anal. Chem. 28:350-356. https://doi.org/10.1021/ ac60111a017.

Fawcett, J. K., and J. E. Scott. 1960. A rapid and precise method for the determination of urea. J. Clin. Pathol. 13:156-159. https://doi .org/10.1136/jcp.13.2.156.

Fiems, L. O., C. V. Boucqué, B. G. Cottyn, and F. X. Buysse. 1985 Evaluation of rapeseed meal with low and high glucosinolates as a protein source in calf starters. Livest. Prod. Sci. 12:131-143. https: //doi.org/10.1016/0301-6226(85)90086-7.

Fisher, L. J. 1980. A comparison of rapeseed meal and soybean meal as a source of protein and protected lipid as a source of supplemental energy for calf starters. Can. J. Anim. Sci. 60:359-366. https://doi .org/10.4141/cjas80-045.

Gerpen, J. V. 2005. Biodiesel processing and production. Fuel Process. Technol. 86:1097-1107. https://doi.org/10.1016/j.fuproc.2004.11 .005 .

Górka, P., Z. M. Kowalski, P. Pietrzak, A. Kotunia, W. Jagusiak, and R. Zabielski. 2011. Is rumen development in newborn calves affected by different liquid feeds and small intestine development? J. Dairy Sci. 94:3002-3013. https://doi.org/10.3168/jds.2010-3499.

Górka, P., Z. M. Kowalski, R. Zabielski, and P. Guilloteau. 2018. Invited review: Use of butyrate to promote gastrointestinal tract development in calves. J. Dairy Sci. 101:4785-4800. https://doi .org/10.3168/jds.2017-14086.

Górka, P., P. Pietrzak, A. Kotunia, R. Zabielski, and Z. M. Kowalski. 2014. Effect of method of delivery of sodium butyrate on maturation of the small intestine in newborn calves. J. Dairy Sci. 97:1026-1035. https://doi.org/10.3168/jds.2013-7251.

Guilloteau, P., M. Plodari, V. Romé, G. Savary, L. Le Normand, and R. Zabielski. 2011. Pancreatic enzyme deficiency depends on dietary protein origin in milk-fed calves. J. Dairy Sci. 94:1517-1525. https://doi.org/10.3168/jds.2010-3906.

Hadam, D., J. Kański, K. Burakowska, G. B. Penner, Z. M. Kowalski, and P. Górka. 2016. Short communication: Effect of canola meal use as a protein source in a starter mixture on feeding behavior and performance of calves during the weaning transition. J. Dairy Sci. 99:1247-1252. https://doi.org/10.3168/jds.2015-10399.

Halestrap, A. P., and N. T. Price. 1999. The proton-linked monocarboxylate transporter (MCT) family: Structure, function and regulation. Biochem. J. 343:281-299. https://doi.org/10.1042/ bj3430281.

Hall, M. B. 2009. Determination of starch, including maltooligosaccharides, in animal feeds: Comparison of methods and a method recommended for AOAC collaborative study. J. AOAC Int. 92:42-49. https://doi.org/10.1093/jaoac/92.1.42.

Hall, M. B., T. D. Nennich, P. H. Doane, and G. E. Brink. 2015. Total volatile fatty acid concentrations are unreliable estimators of treatment effects on ruminal fermentation in vivo. J. Dairy Sci. 98:3988-3999. https://doi.org/10.3168/jds.2014-8854.

Hill, T. M., H. G. Bateman II, J. D. Quigley III, J. M. Aldrich, R. L. Schlotterbeck, and A. J. Heinrichs. 2013. Review: New information on the protein requirements and diet formulation for dairy calves and heifers since the Dairy NRC 2001. Prof. Anim. Sci. 29:199207. https://doi.org/10.15232/S1080-7446(15)30225-4.

Huang, X., N. A. Khan, X. Zhang, and P. Yu. 2015. Effects of canola meal pellet conditioning temperature and time on ruminal and intestinal digestion, hourly effective degradation ratio, and potential nitrogen to energy synchronization in dairy cows. J. Dairy Sci. 98:8836-8845. https://doi.org/10.3168/jds.2014-9295.

Huhtanen, P., M. Hetta, and C. Swensson. 2011. Evaluation of canola meal as a protein supplement for dairy cows: A review and a metaanalysis. Can. J. Anim. Sci. 91:529-543. https://doi.org/10.4141/ cjas2011-029. 
Ingalls, J. R., and M. E. Seale. 1971. Effect of continuous feeding of rapeseed meal on growth of dairy calves and subsequent first lactation yield. Can. J. Anim. Sci. 51:681-686. https://doi.org/10 .4141/cjas71-090.

Kamel, H. E. M., J. Sekine, Z. Morita, and T. Suga. 1995. The effect of frozen-rethawing technique on detaching firmly associated bacteria from in situ hay residues. Can. J. Anim. Sci. 75:481-483. https:// doi.org/10.4141/cjas95-071.

Khan, M. A., A. Bach, D. M. Weary, and M. A. G. Von Keyserlingk. 2016. Invited review: Transitioning from milk to solid feed in dairy heifers. J. Dairy Sci. 99:885-902. https://doi.org/10.3168/jds.2015 $-9975$.

Kholif, A. E. 2019. Glycerol use in dairy diets: A systemic review. Anim. Nutr. 5:209-216. https://doi.org/10.1016/j.aninu.2019.06 .002 .

Khorasani, G. R., E. K. Okine, and J. J. Kennelly. 1996. Forage source alters nutrient supply to the intestine without influencing milk yield. J. Dairy Sci. 79:862-872. https://doi.org/10.3168/jds.S0022 $-0302(96) 76435-4$.

Khorasani, G. R., W. C. Sauer, L. Ozimek, and J. J. Kennelly. 1990. Digestion of soybean meal and canola meal protein and amino acids in the digestive tract of young ruminants. J. Anim. Sci. 68:3421-3428. https://doi.org/10.2527/1990.68103421x.

Lallès, J. P., and C. Poncet. 1990. Changes in ruminal and intestinal digestion during and after weaning in dairy calves fed concentrate diets containing pea or soya bean meal. 1. Digestion of organic matter and nitrogen. Livest. Prod. Sci. 24:129-142. https://doi .org/10.1016/0301-6226(90)90073-F.

Liao, S. F., E. S. Vanzant, D. L. Harmon, K. R. McLeod, J. A. Boling, and J. C. Matthews. 2009. Ruminal and abomasal starch hydrolysate infusions selectively decrease the expression of cationic amino acid transporter mRNA by small intestinal epithelia of forage-fed beef steers. J. Dairy Sci. 92:1124-1135. https://doi.org/10.3168/ jds.2008-1521.

Mach, N., A. Bach, and M. Devant. 2009. Effects of crude glycerin supplementation on performance and meat quality of Holstein bulls fed high-concentrate diets. J. Anim. Sci. 87:632-638. https:/ /doi.org/10.2527/jas.2008-0987.

Maroux, S., D. Louvard, and J. Barath. 1973. The aminopeptidase from hog intestinal brush border. Biochim. Biophys. Acta 321:282295. https://doi.org/10.1016/0005-2744(73)90083-1.

Martineau, R., D. R. Ouellet, and H. Lapierre. 2013. Feeding canola meal to dairy cows: A meta-analysis on lactational responses. J. Dairy Sci. 96:1701-1714. https://doi.org/10.3168/jds.2012-5740.

Maxin, G., D. R. Ouellet, and H. Lapierre. 2013. Ruminal degradability of dry matter, crude protein, and amino acids in soybean meal, canola meal, corn, and wheat dried distillers grains. J. Dairy Sci. 96:5151-5160. https://doi.org/10.3168/jds.2012-6392.

McKinnon, J. J., J. A. Olubobokun, D. A. Christensen, and R. D. H. Cohen. 1991. The influence of heat and chemical treatment on ruminal disappearance of canola meal. Can. J. Anim. Sci. 71:773780. https://doi.org/10.4141/cjas91-092.

McKinnon, J. J., J. A. Olubobokun, A. Mustafa, R. D. H. Cohen, and D. A. Christensen. 1995. Influence of dry heat treatment of canola meal on site and extent of nutrient disappearance in ruminants. Anim. Feed Sci. Technol. 56:243-252. https://doi.org/10.1016/ 0377-8401(95)00828-4.

Mentschel, J., R. Leiser, C. Mülling, C. Pfarrer, and R. Claus. 2001. Butyric acid stimulates rumen mucosa development in the calf mainly by a reduction of apoptosis. Arch. Tierernahr. 55:85-102. https://doi.org/10.1080/17450390109386185.

Miller-Cushon, E. K., C. Montoro, I. R. Ipharraguerre, and A. Bach. 2014a. Dietary preference in dairy calves for feed ingredients high in energy and protein. J. Dairy Sci. 97:1634-1644. https://doi.org/ 10.3168/jds.2013-7199.

Miller-Cushon, E. K., M. Terré, T. J. Devries, and A. Bach. 2014b. The effect of palatability of protein source on dietary selection in dairy calves. J. Dairy Sci. 97:4444-4454. https://doi.org/10.3168/ jds.2013-7816.

Montagne, L., I. Crévieu-Gabriel, R. Toullec, and J. P. Lallès. 2003. Influence of dietary protein level and source on the course of pro- tein digestion along the small intestine of the veal calf. J. Dairy Sci. 86:934-943. https://doi.org/10.3168/jds.S0022-0302(03)73676 -5 .

Nagatsu, T., M. Hino, H. Fuyamada, T. Hayakawa, S. Sakakibara, Y. Nakagawa, and T. Takemoto. 1976. New chromogenic substrates for X-prolyl dipeptidyl-aminopeptidase. Anal. Biochem. 74:466476. https://doi.org/10.1016/0003-2697(76)90227-X.

Nakamura, S., S. Haga, K. Kimura, and S. Matsuyama. 2018. Propionate and butyrate induce gene expression of monocarboxylate transporter 4 and cluster of differentiation 147 in cultured rumen epithelial cells derived from preweaning dairy calves. J. Anim. Sci. 96:4902-4911. https://doi.org/10.1093/jas/sky334.

NCBI (National Center for Biotechnology Information). 2018. PrimerBLAST. Accessed Jun. 17, 2020. https://www.ncbi.nlm.nih.gov/ tools/primer-blast/.

Newkirk, R. W., H. L. Classen, T. A. Scott, and M. J. Edney. 2003. The digestibility and content of amino acids in toasted and nontoasted canola meals. Can. J. Anim. Sci. 83:131-139. https://doi .org/10.4141/A02-028.

NRC. 2001. Nutrient Requirements of Dairy Cattle. 7th rev. ed. National Academies Press, Washington, DC. https://doi.org/10 $.17226 / 9825$.

Obitsu, T., T. Morooka, M. Okubo, and Y. Asahida. 1995. Ruminal and post-ruminal digestion and nitrogen balance in early weaned calves fed soybean meal and heated soybean meal. Asian-Australas. J. Anim. Sci. 8:75-82. https://doi.org/10.5713/ajas.1995.75.

Ørskov, E. R., and I. McDonald. 1979. The estimation of protein degradability in the rumen from incubation measurements weighted according to rate of passage. J. Agric. Sci. 92:499-503. https://doi .org/10.1017/S0021859600063048.

Paiva, P. G., T. A. D. Valle, E. F. Jesus, V. P. Bettero, G. F. Almeida, I. C. S. Bueno, B. J. Bradford, and F. P. Rennó. 2016. Effects of crude glycerin on milk composition, nutrient digestibility and ruminal fermentation of dairy cows fed corn silage-based diets. Anim. Feed Sci. Technol. 212:136-142. https://doi.org/10.1016/j .anifeedsci.2015.12.016.

Pantophlet, A. J., M. S. Gilbert, J. J. G. C. van Den Borne, W. J. J. Gerrits, H. Roelofsen, M. G. Priebe, and R. J. Vonk. 2016. Lactose in milk replacer can partly be replaced by glucose, fructose, or glycerol without affecting insulin sensitivity in veal calves. J. Dairy Sci. 99:3072-3080. https://doi.org/10.3168/jds.2015-10277.

Quigley, J. D. III, L. A. Caldwell, G. D. Sinks, and R. N. Heitmann. 1991. Changes in blood glucose, nonesterified fatty acids, and ketones in response to weaning and feed intake in young calves. J. Dairy Sci. 74:250-257. https://doi.org/10.3168/jds.S0022 $-0302(91) 78167-8$.

Quigley, J. D. III, C. G. Schwab, and W. E. Hylton. 1985. Development of rumen function in calves: Nature of proteins reaching the abomasum. J. Dairy Sci. 68:694-702. https://doi.org/10.3168/jds .S0022-0302(85)80875-4.

Quispe, C. A. G., C. J. R. Coronado, and J. A. Carvalho Jr.. 2013. Glycerol: Production, consumption, prices, characterization and new trends in combustion. Renew. Sustain. Energy Rev. 27:475493. https://doi.org/10.1016/j.rser.2013.06.017.

Ramakers, C., J. M. Ruijter, R. H. L. Deprez, and A. F. M. Moorman. 2003. Assumption-free analysis of quantitative real-time polymerase chain reaction (PCR) data. Neurosci. Lett. 339:62-66. https://doi.org/10.1016/S0304-3940(02)01423-4.

Ramos, M. H., and M. S. Kerley. 2012. Effect of dietary crude glycerol level on ruminal fermentation in continuous culture and growth performance of beef calves. J. Anim. Sci. 90:892-899. https://doi .org/10.2527/jas.2011-4099.

Rémond, B., E. Souday, and J. P. Jouany. 1993. In vitro and in vivo fermentation of glycerol by rumen microbes. Anim. Feed Sci. Technol. 41:121-132. https://doi.org/10.1016/0377-8401(93)90118-4.

Rojek, A., J. Praetorius, J. Frøkiaer, S. Nielsen, and R. A. Fenton. 2008. A current view of the mammalian aquaglyceroporins. Annu. Rev. Physiol. 70:301-327. https://doi.org/10.1146/annurev.physiol .70.113006.100452.

Røjen, B. A., S. B. Poulsen, P. K. Theil, R. A. Fenton, and N. B. Kristensen. 2011. Short communication: Effects of dietary nitrogen 
concentration on messenger RNA expression and protein abundance of urea transporter-B and aquaporins in ruminal papillae from lactating Holstein cows. J. Dairy Sci. 94:2587-2591. https:// doi.org/10.3168/jds.2010-4073.

Roth, B. A., N. M. Keil, L. Gygax, and E. Hillmann. 2009. Influence of weaning method on health status and rumen development in dairy calves. J. Dairy Sci. 92:645-656. https://doi.org/10.3168/ jds.2008-1153.

Sander, E. G., R. G. Warner, H. N. Harrison, and J. K. Loosli. 1959. The stimulatory effect of sodium butyrate and sodium propionate on the development of rumen mucosa in the young calf. J. Dairy Sci. 42:1600-1605. https://doi.org/10.3168/jds.S0022 -0302(59)90772-6.

Schingoeth, D. J., G. L. Beardsley, and L. D. Muller. 1974. Evaluation of commercial rapeseed meal and Bronowski variety rapeseed meal in calf rations. J. Nutr. 104:558-562. https://doi.org/10.1093/jn/ 104.5.558.

Smith, P. K., R. I. Krohn, G. T. Hermanson, A. K. Mallia, F. H. Gartner, M. D. Provenzano, E. K. Fujimoto, N. M. Goeke, B. J. Olson, and D. C. Klenk. 1985. Measurement of protein using bicinchoninic acid. Anal. Biochem. 150:76-85. https://doi.org/10 .1016/0003-2697(85)90442-7.

Stake, P. E., M. J. Owens, and D. J. Schingoethe. 1973. Rapeseed, sunflower, and soybean meal supplementation of calf rations. J. Dairy Sci. 56:783-788. https://doi.org/10.3168/jds.S0022-0302(73)85250 -6 .

van Soest, P. J., and V. C. Mason. 1991. The influence of the Maillard reaction upon the nutritive value of fibrous feeds. Anim. Feed Sci. Technol. 32:45-53. https://doi.org/10.1016/0377-8401(91)90008 $-\mathrm{G}$.

van Soest, P. J., J. B. Robertson, and B. A. Lewis. 1991. Methods for dietary fiber, neutral detergent fiber, and nonstarch polysaccharides in relation to animal nutrition. J. Dairy Sci. 74:3583-3597. https://doi.org/10.3168/jds.S0022-0302(91)78551-2.

Vazquez-Anon, M., A. J. Heinrichs, J. M. Aldrich, and G. A. Varga. 1993. Effect of postweaning age on rate of in situ protein disappearance in calves weaned at 5 weeks of age. J. Dairy Sci. 76:27492757. https://doi.org/10.3168/jds.S0022-0302(93)77612-2.

Verdugo, A. C. 2016. Effect of lipid supplementation on ruminal epithelial membrane fatty acid composition and short-chain fatty acid absorption. MS Thesis. Department of Animal and Poultry Science, University of Saskatchewan, Saskatoon, SK, Canada.
Walpole, M. E., B. Schurmann, P. Górka, G. Penner, M. Loewen, and T. Mutsvangwa. 2015. Serosal-to-mucosal urea flux across the isolated ruminal epithelium is mediated via urea transporter-B and aquaporins when Holstein calves are abruptly changed to a moderately fermentable diet. J. Dairy Sci. 98:1204-1213. https:// doi.org/10.3168/jds.2014-8757.

Wang, A., Z. Gu, B. Heid, R. M. Akers, and H. Jiang. 2009. Identification and characterization of the bovine $\mathrm{G}$ protein-coupled receptor GPR41 and GPR43 genes. J. Dairy Sci. 92:2696-2705. https://doi .org/10.3168/jds.2009-2037.

Weary, D. M., J. Jasper, and M. J. Hötzel. 2008. Understanding weaning distress. Appl. Anim. Behav. Sci. 110:24-41. https://doi.org/ 10.1016/j.applanim.2007.03.025.

Werner Omazic, A., C. Kronqvist, L. Zhongyan, H. Martens, and K. Holtenius. 2015. The fate of glycerol entering the rumen of dairy cows and sheep. J. Anim. Physiol. Anim. Nutr. (Berl.) 99:258-264. https://doi.org/10.1111/jpn.12245.

Werner Omazic, A., M. Tråvén, S. Roos, E. Mellgren, and K. Holtenius. 2013. Oral rehydration solution with glycerol to dairy calves: Effects on fluid balance, metabolism, and intestinal microbiota. Acta Agric. Scand. A Anim. Sci. 63:1-10. https://doi.org/ 10.1080/09064702.2013.785585.

Williamson, D. H., J. Mellanby, and H. A. Krebs. 1962. Enzymic determination of $\mathrm{d}(-)-\beta$-hydroxybutyric acid and acetoacetic acid in blood. Biochem. J. 82:90-96. https://doi.org/10.1042/bj0820090.

Wu, B., and E. Beitz. 2007. Aquaporins with selectivity for unconventional permeants. Cell. Mol. Life Sci. 64:2413-2421. https://doi .org/10.1007/s00018-007-7163-2.

Yohe, T. T., H. Schramm, C. L. M. Parsons, R. R. White, and K. M. Daniels. 2018. Technical note: Infusion, sampling, and vacuum-assisted collection devices for use in ruminally cannulated calves. J. Dairy Sci. 101:9065-9071. https://doi.org/10.3168/jds.2018-14651.

\section{ORCIDS}

P. Górka @ https://orcid.org/0000-0002-4278-0493

Z. M. Kowalski $\odot$ https://orcid.org/0000-0003-3935-9531

G. B. Penner (ㄴ) https://orcid.org/0000-0002-6396-2130 